\title{
Development and validation of a productive liquid chromatography- tandem mass spectrometry method for the analysis of androgens, estrogens, glucocorticoids and progestagens in human serum
}

Michele Iannone $^{1 \S}$, Anna Pia Dima ${ }^{2,3 \S}$, Francesca Sciarra ${ }^{2}$, Francesco Botrè ${ }^{1,2, \# *}$ and Andrea M. Isidori ${ }^{2}$

1. Laboratorio Antidoping FMSI, Largo Onesti 1, 00197 Rome, Italy

2. Department of Experimental Medicine, “Sapienza” University of Rome, Viale Regina Elena, 291, 00161 Roma, Italy

3. Analytical Development \& Validation, Merck Italia, Via Luigi Einaudi, 11, 00012 Guidonia RM

\# Present address: REDs - Research and Expertise in antiDoping sciences, ISSUL - Institute of sport sciences, University of Lausanne, Synathlon, Quartier Centre, 1015 Lausanne Switzerland

$\S$ Equally contributed

* Corresponding author 
medRxiv preprint doi: https://doi.org/10.1101/2021.04.12.21255305; this version posted April 19, 2021. The copyright holder for this preprint (which was not certified by peer review) is the author/funder, who has granted medRxiv a license to display the preprint in perpetuity.

All rights reserved. No reuse allowed without permission.

\section{Abstract}

Adrenal and gonadal disorders are very often coupled, due to common etiology or pathophysiology. We present the development, validation and application of a liquid chromatography tandem mass spectrometry (LC-MS/MS) method for the simultaneous analysis of androgens (androstenedione (A4), testosterone (T), dihydrotestosterone (DHT), and dehydroepiandrosterone sulfate (DHEA-S)), estrogens (estrone (E1), estradiol (E2), estriol (E3)), glucocorticoids (cortisol (F), cortisone (E), corticosterone (B), 11-deoxycortisol (S), 21-deoxycortisol (21DF), 11-deoxycorticosterone (11DB)),

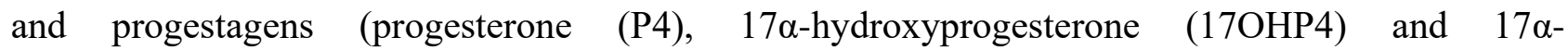
hydroxypregnenolone (17OHP5)) in human serum for clinical use. Samples (250 \&[mu]L of matrix) spiked with isotopic labelled internal standards were extracted with tert-butylmethyl ether (TBME) prior to LC-MS/MS analysis. The chromatographic separation of the underivatized endogenous steroids was achieved on a reversed-phase column (C18 Zorbax Eclipse Plus) using a methanol-water gradient. The LC column was coupled to a triple quadrupole mass spectrometer equipped with an electrospray (ESI) source operating both in positive and in negative mode, with acquisition in multiple reaction mode. The method was validated using surrogated matrices and human serum samples. The proposed method was proven to be specific for all the considered steroids; and linearity was also assessed $\left(\mathrm{R}^{2}>0.99\right)$ in the ranges of quantification investigated. The lower limits of quantification (LLOQs) were in the range of $10-400 \mathrm{pg} / \mathrm{mL}$ depending on the target steroid. Accuracy was in the range 80 - 120\% for all the target compounds, the extraction recovery was higher than $65 \%$ for all the steroids considered and no remarkable matrix effect, expressed in terms of ion enhancement and ion suppression, was observed. To test the reliability of the developed and validated method, the analysis of serum samples collected from ten healthy subjects $(5 \mathrm{M} / 5 \mathrm{~F})$ was performed. In the clinical settings there is a growing need to develop accessible methods for full steroid hormone profiling. The dynamic link between steroidogenic glands and liver enzymatic processing (activation and clearance) attributes to the profile a much greater clinical meaning than a set of individually measured hormones. The presented method can be used to identify trajectories of deviation from the concentration normality ranges applied to disorders of the gonadal and adrenal axes. 
medRxiv preprint doi: https://doi.org/10.1101/2021.04.12.21255305; this version posted April 19, 2021. The copyright holder for this preprint (which was not certified by peer review) is the author/funder, who has granted medRxiv a license to display the preprint in perpetuity.

All rights reserved. No reuse allowed without permission.

\section{Introduction}

Steroid hormones are a class of endogenous substances characterized by a sterane skeleton composed by 4 fused rings (three cyclohexane and one cyclopentane), sustaining important role in various physiological functions (e.g., development, sexual differentiation, reproduction, pregnancy, stress, metabolism, immune modulation). The biosynthesis of steroid hormones occurs only in highly specialized tissues (i.e., adrenal cortex glands, gonads, placenta).Their biological effects, however, are significantly influenced by peripheral tissue enzymatic conversion. For example, cortisol can be inactivated and re-activated by the 11-beta-hydrosteroid-dehidrogenase type 1 in the liver (Isidori, 2003), while testosterone can be aromatized into estradiol or reduced to di-hydro-testosterone (Othonos, 2020), triggering important systemic effects. The precise and accurate quantification of endogenous steroid hormones, and their intermediate products, in plasma, serum or dried blood spots (DBSs) represents a powerful tool for the investigation of the hormone status, the early identification of endocrinological disorders , and follow-up under therapeutic interventions (Giannetta 2012; Pofi, 2018) . For indeed, steroid diagnostic is also employed for the diagnosis of a series of adrenal (Minnetti, 2020), sexual (Aversa, 2004), and reproductive disorders (Isidori, 2006), including those related to sexual differentiation, gonadal function as well as precocious puberty and polycystic ovary disease (PCOS) (Minutti, 2004; Peitzsch, 2015; Handelsman, 2017; Taylor, 2017).

In clinical laboratories, the routine methods mainly used since now for the detection and quantitation of endogenous steroids in blood (serum and/or plasma) are immunoassays, which can utilize either radioactive or non-radioactive markers, and belong to the excess-antigen/limited-antibody type immunoassays. These analytical methods, which in most of the cases are available as kits, are used because of their noteworthy advantages in terms of costs and automation, but, at the same time, they present a series of major limitations (Auchus, 2014; Handelsman, 2017). Commercial diagnostic kits, in fact, are often characterized by poor antibody specificity, due to the cross reactivities with structurally similar metabolites (poor accuracy) especially in the low concentration ranges; furthermore, they present limitation in sensitivity, may be affected by matrix interferences (which cannot be corrected by the use of suitable internal standards); finally, their dynamic range is quite limited and highly variable among different kits and different laboratories. Another serious drawback of immunoassay-based methods is represented by the impossibility to perform multiple analytes analysis in the same session and on the same sample aliquot, leading to a significant waste of sample volume and longer overall analysis time (Ismail, 2002; Stanczyk, 2003; Rosner, 2007; Koal, 2012), introducing errors in the relative ratios between hormones and their metabolites 
medRxiv preprint doi: https://doi.org/10.1101/2021.04.12.21255305; this version posted April 19, 2021. The copyright holder for this preprint (which was not certified by peer review) is the author/funder, who has granted medRxiv a license to display the preprint in perpetuity.

All rights reserved. No reuse allowed without permission.

Because of the limitations in terms of sensitivity, accuracy, precision and specificity of the immunoassay-based analytical method for the identification and quantification of endogenous steroids in blood matrices, numerous methods based on gas chromatography (GC) or liquid chromatography (LC) coupled to mass spectrometry (MS) have been developed for clinical applications in the last years. Chromatographic-mass spectrometric methods present significant improvements with respect to immunoassays in terms of selectivity and sensitivity (Shackleton, 1990; Wolthers, 1999; Vogaser, 2007; Soldin, 2009; Krone, 2010; Shackleton, 2010; Grebe, 2011; Kushnir, 2011; Carvalho, 2012; Keevil, 2016; Shackleton, 2018).

The GC-MS ${ }^{\mathrm{n}}$ analysis of the urinary steroid profile, as well as of the urinary excretion of synthetic steroids, is an analytical approach that remains unrivaled in forensic sciences (i. e. antidoping analysis, toxicological applications) (Narducci, 1990; Buiarelli, 2001; Peng, 2002; Frati, 2015; Palermo, 2016; Stoll, 2020 a; Stoll, 2020 b; Iannone, 2020). At the same time, GC-MS has also been proven very useful for the unequivocal identification of different well-characterized steroid metabolic disorders, like 21-hydroxylase deficiency and hypogonadism (Caulfield, 2002; Di Luigi, 2009; Di Luigi, 2012; Iannone, 2019; Storbeck, 2019). However, in the last 10-15 years, GC-MS ${ }^{\mathrm{n}}$ analysis of urinary endogenous steroids for clinical application has been progressively superseded by LC-MS or LC coupled to high resolution mass spectrometer (i. e. orbitrap, time-of-flight), whose applications also included the analysis of blood matrices. For indeed, methods based on liquid chromatography coupled to mass spectrometry allow to bypass the derivatization step, necessary in GC-MS ${ }^{\mathrm{n}}$ analysis to generate volatile and thermally stable compounds. Furthermore, analysis of the target steroid levels in blood could also reduce the utility of the analysis of the entire volume of urine excreted in 24 hours (Ceglarek, 2009; Fanelli, 2011; Keski-Rahkonen, 2011; Gaudl, 2016; Matysik, 2016; Ponzetto, 2016; Ponzetto, 2017; Taylor, 2017; Hakkinen, 2018; Liu, 2019), with a significant improvement both in the logistics of sample collection and analysis, and in the rapidity of the result turnaround. Nonetheless, GC-MS ${ }^{\mathrm{n}}$ still remains unrivaled in the case highest chromatographic resolution is essential, for instance for the unambiguous identification of synthetic steroid isomers.

To date, as reported in the recommendations of different Endocrine Societies (Isidori, 2015; Isidori, 2020), high-quality and well-validate LC-MS/MS methods for the identification and quantification of endogenous steroids in blood (serum and/or plasma), are the methods of choice for use in the clinical laboratory, thanks to the simultaneous detection of multi-class hormones during a single injection. We are here proposing the development, validation and application of a simplified liquidchromatography tandem mass spectrometry (LC-MS/MS) method for the analysis of 16 endogenous steroid hormones belonging to the classes of androgens (androstenedione (A4), testosterone (T), dihydrotestosterone (DHT), and dehydroepiandrosterone sulfate (DHEA-S)), estrogens (estrone (E1), 
medRxiv preprint doi: https://doi.org/10.1101/2021.04.12.21255305; this version posted April 19, 2021. The copyright holder for this preprint (which was not certified by peer review) is the author/funder, who has granted medRxiv a license to display the preprint in perpetuity.

All rights reserved. No reuse allowed without permission.

estradiol (E2), estriol (E3)), glucocorticoids (cortisol (F), cortisone (E), corticosterone (B), 11deoxycortisol (S), 21-deoxycortisol (21DF), 11-deoxycorticosterone (11DB)), and progestagens (progesterone (P4), 17 $\alpha$-hydroxyprogesterone (17OHP4) and 17 $\alpha$-hydroxypregnenolone (17OHP5)) with the aim to obtain a pathway-driven serum steroid profile which could be used in clinical routine analysis (Figure 1). The method here presented is based on a simple liquid-liquid extraction with tertbutylmethyl ether (TBME) by-passing a possible intricate solid phase extraction (SPE) procedure and a time-consuming derivatization step. The method has been fully validated according to the requirements of ISO17025/ISO15189, and its overall analytical performance has been assessed by the analysis of real samples collected from male and female subjects. 
medRxiv preprint doi: https://doi.org/10.1101/2021.04.12.21255305; this version posted April 19, 2021. The copyright holder for this preprint (which was not certified by peer review) is the author/funder, who has granted medRxiv a license to display the preprint in perpetuity.

\section{Materials and methods}

\section{Chemicals and reagents}

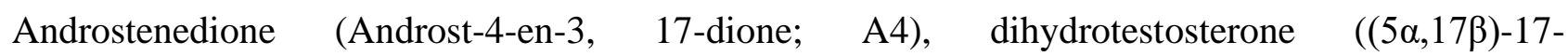
Hydroxyandrostan-3-one; DHT), 17 $\alpha$-hydroxyprogesterone (17-Hydroxypregn-4-ene-3,20-dione; 17OHP4), 17 $\alpha$-hydroxypregnenolone ((3ß)-3, 17-Dihydroxypregn-5-en-20-one; 17OHP5), progesterone (Pregn-4-ene-3,20-dione; P4), cortisone (17,21-Dihydroxypregn-4-ene-3, 11, 20-trione; E), cortisol ((11ß)-11, 17, 21-Trihydroxypregn-4-ene-3,20-dione; F), 11-deoxycortisol (17, 21-

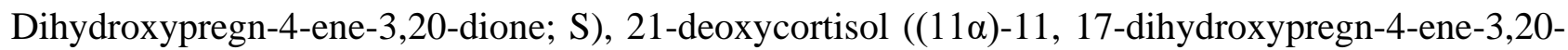
dione; 21DF), corticosterone ((11ß)-11, 21-Dihydroxypregn-4-ene-3,20-dione; B), 11deoxycorticosterone (21-Hydroxypregn-4-ene-3,20-dione; 11DB), estrone (3-Hydroxyestra1(10),2,4-trien-17-one; E1), estradiol ((17ß)-Estra-1(10),2,4-triene-3, 17-diol; E2), estriol ((16 $\alpha, 17 \beta)$-Estra-1,3,5(10)-triene-3, 16, 17-triol; E3) and the isotopic labeled internal standards 17 $\alpha$ hydroxyprogesterone-d8 (17OHP4-d8), 17 $\alpha$-hydroxypregnenolone-d3 (17OHP5-d3), cortisone-d8 (E-d8), cortisol-d4 (F-d4), 11-deoxycortisol-d7 (S-d7), 21-deoxycortisol-d8 (21DF-d8), corticosterone- $d 8$ (B- $d 8)$ and 11-deoxycorticosterone- $d 7$ (11DB- $d 7$ ) were from Cambridge Isotope Laboratories Inc. (Tewksbury, MA, USA). Testosterone ((17 $\beta)$-17-Hydroxyandrost-4-en-3-one; T), dehydroepiandrosterone sulfate ((3ß)-17-Oxoandrost-5-en-3-yl hydrogen sulfate; DHEA-S) and the isotopic labeled internal standard progesterone- $d 7$ (P4- $d 7$ ), estradiol- $d 2$ (E2- $d 2)$, testosterone- $d 3$ (Td3) and dehydroepiandrosterone sulfate-d5 (DHEA-S-d5) were purchased from Sigma Aldrich (Milano, Italy). The HPLC grade solvents (acetonitrile, methanol, tert-butylmethyl ether (TBME)), ammonium fluoride $\left(\mathrm{NH}_{4} \mathrm{~F}\right)$, phosphate buffer (PBS) bovine serum albumin (BSA) $96 \% \mathrm{w} / \mathrm{V}$ and the ultra-purified water were from Sigma Aldrich (Milano, Italy). Carbonate/bicarbonate buffer solution was purchased from Carlo Erba (Milano, Italy).

\section{Stock solutions, calibrators and in-house quality control}

Stock solution of each analytes and isotope labelled internal standards were prepared in methanol at concentration of $1 \mathrm{mg} / \mathrm{mL}$. Each analyte stock solution was diluted and combined to obtain a series of working solutions in the range of concentrations $0,1 \mathrm{ng} / \mathrm{mL}-100 \mu \mathrm{g} / \mathrm{mL}$. The internal standard (ISTD) working solution was obtained by mixing and diluting all the isotope labelled stock solution (testosterone- $d 3$ (T-d3), dehydroepiandrosterone sulfate- $d 5$ (DHEA-S-d5), estradiol-d2 (E2-d2), cortisol-d4 (F-d4), cortisone- $d 8$ (E- $d 8)$, corticosterone-d8 (B-d8), 11-deoxycortisol- $d 7$ (S-d7), 21deoxycortisol-d8 (21DF- $d 8), 11$-deoxycorticosterone- $d 7$ (11DB- $d 7)$, progesterone- $d 7$ (P4- $d 7), 17 \alpha-$ hydroxyprogesterone-d8 (17OHP4-d8), 17 $\alpha$-hydroxypregnenolone-d3 (17OHP5-d3)) to obtain a 
medRxiv preprint doi: https://doi.org/10.1101/2021.04.12.21255305; this version posted April 19, 2021. The copyright holder for this preprint (which was not certified by peer review) is the author/funder, who has granted medRxiv a license to display the preprint in perpetuity.

All rights reserved. No reuse allowed without permission.

final concentration of $1 \mathrm{ng} / \mathrm{mL}$ for all deuterated standards except for DHEA-S-d5 which final concentration is of $10 \mathrm{ng} / \mathrm{mL}$. All solutions were stored at $-20^{\circ} \mathrm{C}$.

Due to the lack of a steroids-free matrix, calibration samples were prepared in a surrogate matrix consisting in a solution of bovine serum albumin (BSA) in phosphate buffer solution (PBS) 4\% w/V. One blank, a zero-point level and seven levels of calibrators were used for each compound (10 pg/mL - $10 \mathrm{ng} / \mathrm{mL}$ for androstenedione (A4), testosterone (T), 11-deoxycortisol (S), 21-deoxycortisol (21DF), 11-deoxycorticosterone (11DB); $40 \mathrm{pg} / \mathrm{mL}$ - $40 \mathrm{ng} / \mathrm{mL}$ for dihydrotestosterone (DHT), estrone (E1), estradiol (E2), estriol (E3), corticosterone (B), progesterone (P4), 17 $\alpha$ hydroxyprogesterone (17OHP4) and 17 $\alpha$-hydroxypregnenolone (17OHP5); $100 \mathrm{pg} / \mathrm{mL}-100 \mathrm{ng} / \mathrm{mL}$ for cortisol (F) and cortisone (E); $400 \mathrm{pg} / \mathrm{mL}$ - $1000 \mathrm{ng} / \mathrm{mL}$ for dehydroepiandrosterone sulfate (DHEA-S)), according to their reference concentration ranges (Fanelli, 2011; Eisenhofer, 2017; Schiffer, 2019).

The in-house quality control samples (IQCs) were obtained by pooled human serum from volunteers' donors. According to the calibration ranges considered in the present work, three levels (low, medium and high) were generated after the addition of a certain volume of methanolic working solutions to the pooled serum. For androstenedione (A4), testosterone (T), 11-deoxycortisol (S), 21-deoxycortisol (21DF), 11-deoxycorticosterone (11DB) the IQCs samples were prepared at $40 \mathrm{pg} / \mathrm{mL}$ (low), $1 \mathrm{ng} / \mathrm{mL}$ (medium) and $10 \mathrm{ng} / \mathrm{mL}$ (high); for dihydrotestosterone (DHT), estrone (E1), estradiol (E2), estriol (E3), corticosterone (B), progesterone (P4), 17 $\alpha$-hydroxyprogesterone (17OHP4) and 17 $\alpha$ hydroxypregnenolone (17OHP5) the IQCs samples were prepared at $100 \mathrm{pg} / \mathrm{mL}$ (low), $4 \mathrm{ng} / \mathrm{mL}$ (medium) and $40 \mathrm{ng} / \mathrm{mL}$ (high); for cortisol (F) and cortisone (E) the IQCs samples were prepared at $400 \mathrm{pg} / \mathrm{mL}$ (low), $10 \mathrm{ng} / \mathrm{mL}$ (medium) and $100 \mathrm{ng} / \mathrm{mL}$ (high); finally for dehydroepiandrosterone sulfate (DHEA-S) the IQCs samples were prepared at $1 \mathrm{ng} / \mathrm{mL}$ (low), $40 \mathrm{ng} / \mathrm{mL}$ (medium) and 1000 $\mathrm{ng} / \mathrm{mL}$ (high). The standard working solution used to prepare the IQCs are independently with the respect to the solution used for preparation of the calibration samples.

The analysis of IQCs was necessary to assess the performances of developed method in terms of accuracy and precision.

\section{Sample pre-treatment}

Serum samples were thawed at room temperature and together with blanks, calibration samples and IQCs freshly prepared were processed as follow: aliquots of $250 \mu \mathrm{L}$ were transferred into $2 \mathrm{~mL}$ polypropylene tubes and $25 \mu \mathrm{L}$ of ISTD working solution was added. Samples were equilibrated on a mechanical shaker for $5 \mathrm{~min}$. After this period $150 \mu \mathrm{L}$ of carbonate/bicarbonate buffer solution (pH 9,5) and 1,5 mL of TBME were added and tubes were vortexed for $5 \mathrm{~min}$ and the centrifuged at 10000 
medRxiv preprint doi: https://doi.org/10.1101/2021.04.12.21255305; this version posted April 19, 2021. The copyright holder for this preprint (which was not certified by peer review) is the author/funder, who has granted medRxiv a license to display the preprint in perpetuity.

All rights reserved. No reuse allowed without permission.

rpm for $10 \mathrm{~min}$. After centrifugation, the organic layers were transferred into glass tubes and evaporated to dryness under nitrogen stream at $55^{\circ} \mathrm{C}$. The dried extracts were reconstituted in $50 \mu \mathrm{L}$ of water/methanol (85/15 V/V) and then injected into the LC-MS/MS system.

\section{Instrumentation and LC-MS/MS conditions}

The liquid chromatography (LC) system consisted of an Agilent ultra-high performance liquid chromatography (UHPLC) Infinity 1290 II (Agilent Technologies, Santa Clara, USA) equipped with a G7116B autosampler, a G7120A 1290 high speed pump and coupled to an Agilent triple quadrupole tandem mass spectrometer (MS/MS) detector 6495 (Agilent Technologies, Santa Clara, USA) [https://web.uniroma1.it/dip_dms/laboratorio-lc-ms-ms]. An electrospray (ESI) ionization source, operating both in positive and in negative mode, was used. The chromatographic separation was carried out using a C18 Zorbax Eclipse Plus column (i. d: 2,1 mm; l: 50 mm; particle size: 1,8 $\mu \mathrm{m}$, CPS Analitica, Milano, Italy). The mobile phase consisted of $\mathrm{NH}_{4} \mathrm{~F} 0,2 \mathrm{mM}$ in water as solvent $\mathrm{A}$ and of $\mathrm{NH}_{4} \mathrm{~F} 0,2 \mathrm{mM}$ in methanol as solvent $\mathrm{B}$. The total run time was of $16 \mathrm{~min}$. The gradient was set as follow: 0-2 min 15-55\% B, 2-5 min 55-45\% B, 5-12 min 55-70\% B, 12-13 min 70-95\% B. The column was flushed for $2 \mathrm{~min}$ at 95\% B channeling the solvent flush in the waste to prevent the contamination of the capillary. Finally, the system was re-equilibrated for 3 min with $15 \%$ of $\mathrm{B}$. The flow rate was set at $400 \mu \mathrm{L} / \mathrm{min}$ and column temperature at $40^{\circ} \mathrm{C}$. An 8 sec needle wash was used between each injection.

Mass spectrometry conditions were optimized as follow: gas temperature of $200^{\circ} \mathrm{C}$, capillary and noozle voltage of $3000 \mathrm{~V}$ and $1500 \mathrm{~V}$ respectively, drying gas flow of $14 \mathrm{~L} / \mathrm{min}$, sheat gas flow of 11 $\mathrm{L} / \mathrm{min}$. The nebulizer gas was set at $20 \mathrm{psi}$ and the sheat gas temperature at $250^{\circ} \mathrm{C}$. The ion funnel parameters were optimized as follow: high-pressure RF of $200 \mathrm{~V}(\mathrm{ESI}+)$ and $90 \mathrm{~V}(\mathrm{ESI}-)$, lowpressure RF of $100 \mathrm{~V}(\mathrm{ESI}+)$ and $60 \mathrm{~V}$ (ESI -).

\section{Method validation}

The validation of the presented analytical method was carried out according to the U. S. Food and Drug Administration (FDA) Guidelines considering the additional issues for endogenous compounds (Food and Drug Administration, 2018). The validation was accomplished in terms of selectivity/specificity, sensitivity, linearity, extraction recovery, accuracy, intra- and inter-assay precision, matrix effect, carry over and stability.

Selectivity and specificity 
medRxiv preprint doi: https://doi.org/10.1101/2021.04.12.21255305; this version posted April 19, 2021. The copyright holder for this preprint (which was not certified by peer review) is the author/funder, who has granted medRxiv a license to display the preprint in perpetuity.

All rights reserved. No reuse allowed without permission.

Selectivity is the extent to which the method can determine a particular compound in the analyzed matrices without interference from matrix components; specificity is defined as the ability of the method to assess, unequivocally, the analyte in the presence of other components that are expected to be present (i. e. impurities, degradation products).

To determine selectivity and specificity six blank samples, six zero calibrator samples and six samples at $\pm 20 \%$ of LLOQ were analyzed in the same analytical session to exclude the presence of interferences at retention times of all analytes and internal standards. These experiments were done in spiked surrogate matrices because of the endogenous nature of the steroids included in the presented method. Despite this, the ratios between quantifier/qualifiers transitions obtained after the analysis of the spiked surrogate samples were compared with the ratios between quantifier/qualifiers transitions obtained after the analysis of a methanolic standard mixture at LLOQ and of all real samples analyzed with the presented method as proof of concept.

\section{Sensitivity and lower limits of quantification (LLOQs)}

Sensitivity is defined as the lowest analyte concentration in the matrix that can be unambiguously identified; the lower limit of quantification (LLOQ) is the lowest amount of an analyte that can be quantitatively determined with acceptable precision and accuracy.

LLOQ was determined, for each pseudo-endogenous steroid included in the method, such as the lowest concentration with an accuracy of 80-120 \%, a CV $<20 \%$ and a five-fold response with the respect to the zero-calibrator (a blank sample to which the internal standard is added), by the analysis of at least six replicates.

\section{Linearity/calibration curves}

Calibration curve is the relationship between the instrument response and the calibration standards within the quantitation and linearity range of the method.

A seven-point calibration curve was analyzed for each pseudo-endogenous steroid included in the study. The linearity was determined in the range $10 \mathrm{pg} / \mathrm{mL}-10 \mathrm{ng} / \mathrm{mL}$ for androstenedione (A4), testosterone (T), 11-deoxycortisol (S), 21-deoxycortisol (21DF), 11-deoxycorticosterone (11DB); in the range $40 \mathrm{pg} / \mathrm{mL}$ - $40 \mathrm{ng} / \mathrm{mL}$ for dihydrotestosterone (DHT), estrone (E1), estradiol (E2), estriol (E3), corticosterone (B), progesterone (P4), 17 $\alpha$-hydroxyprogesterone (17OHP4) and 17 $\alpha$ hydroxypregnenolone (17OHP5); in the range $100 \mathrm{pg} / \mathrm{mL}-100 \mathrm{ng} / \mathrm{mL}$ for cortisol (F) and cortisone (E) and in the range $400 \mathrm{pg} / \mathrm{mL}$ - $1000 \mathrm{ng} / \mathrm{mL}$ for dehydroepiandrosterone sulfate (DHEA-S). The reported linearity ranges were investigated according to the reference concentration ranges described for each compound under study (Fanelli, 2011; Eisenhofer, 2017; Schiffer, 2019). 
medRxiv preprint doi: https://doi.org/10.1101/2021.04.12.21255305; this version posted April 19, 2021. The copyright holder for this preprint (which was not certified by peer review) is the author/funder, who has granted medRxiv a license to display the preprint in perpetuity.

\section{Extraction recovery}

Recovery refers to the extraction efficiency of an analytical process, reported as a percentage of the known amount of an analyte carried through the sample extraction and processing step of the method. Extraction recoveries was calculated at three different levels (40 pg/ml, $1 \mathrm{ng} / \mathrm{ml}$ and $10 \mathrm{ng} / \mathrm{mL}$ for androstenedione (A4), testosterone (T), 11-deoxycortisol (S), 21-deoxycortisol (21DF), 11deoxycorticosterone (11DB); $100 \mathrm{pg} / \mathrm{mL}, 4 \mathrm{ng} / \mathrm{mL}$ and $40 \mathrm{ng} / \mathrm{mL}$ for dihydrotestosterone (DHT), estrone (E1), estradiol (E2), estriol (E3), corticosterone (B), progesterone (P4), 17 $\alpha-$ hydroxyprogesterone (17OHP4) and 17a-hydroxypregnenolone (17OHP5); $400 \mathrm{pg} / \mathrm{mL}, 10 \mathrm{ng} / \mathrm{mL}$ and $100 \mathrm{ng} / \mathrm{mL}$ for cortisol (F) and cortisone (E); $1 \mathrm{ng} / \mathrm{mL}, 40 \mathrm{ng} / \mathrm{mL}$ and $1000 \mathrm{ng} / \mathrm{mL}$ for dehydroepiandrosterone sulfate (DHEA-S)) by comparing the results obtained after the analysis of samples ( $\mathrm{n}=$ six for each concentration levels) spiked with all the compounds considered in the study before sample pre-treatment with the results obtained after the analysis of a second aliquot of the same samples ( $\mathrm{n}=$ six for each concentration levels) spiked with all steroid considered after liquidliquid extraction.

\section{Accuracy and precision}

Accuracy is defined as the degree of closeness of the determined value to the nominal or known true value under prescribed conditions while precision is the closeness of agreement (i. e. degree of scatter) among a series of measurement obtained from multiple sampling of the same homogenous sample under the prescribed conditions.

Both accuracy and precision were investigated by the analysis of in-house quality control samples (IQCs, $\mathrm{n}=$ six for each condition) at four different concentration levels - LLOQ, low, medium and high - (10 pg/mL, $40 \mathrm{pg} / \mathrm{ml}, 1 \mathrm{ng} / \mathrm{ml}$ and $10 \mathrm{ng} / \mathrm{mL}$ for androstenedione (A4), testosterone (T), 11deoxycortisol (S), 21-deoxycortisol (21DF), 11-deoxycorticosterone (11DB); 40 pg/mL, 100 pg/mL, $4 \mathrm{ng} / \mathrm{mL}$ and $40 \mathrm{ng} / \mathrm{mL}$ for dihydrotestosterone (DHT), estrone (E1), estradiol (E2), estriol (E3),

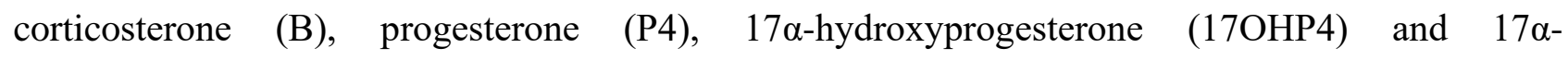
hydroxypregnenolone (17OHP5); 100 pg/mL, 400 pg/mL, 10 ng/mL and 100 ng/mL for cortisol (F) and cortisone (E); $400 \mathrm{pg} / \mathrm{mL}, 1 \mathrm{ng} / \mathrm{mL}, 40 \mathrm{ng} / \mathrm{mL}$ and $1000 \mathrm{ng} / \mathrm{mL}$ for dehydroepiandrosterone sulfate (DHEA-S)). The analysis was performed in one day (intra-day measurement) and in three consecutive days (inter-day measurement). The values of accuracy should be 85-115 \% (80-120 \% for the LLOQ level) with the respect to the nominal value and precision, measured as the coefficient of variation (CV) of the measurement, should be not higher than $15 \%$ (20 \% for LLOQ level). 
medRxiv preprint doi: https://doi.org/10.1101/2021.04.12.21255305; this version posted April 19, 2021. The copyright holder for this preprint (which was not certified by peer review) is the author/funder, who has granted medRxiv a license to display the preprint in perpetuity.

\section{Matrix effect}

The matrix effect is a direct or indirect alteration or interference in response because of the presence of unintended analytes (for analysis) or other interfering substances in the samples.

To evaluate the matrix effect, the results obtained after the analysis of six water samples fortified with all the steroids considered in the method (final concentration $1 \mathrm{ng} / \mathrm{mL}$ for androstenedione (A4), testosterone (T), 11-deoxycortisol (S), 21-deoxycortisol (21DF), 11-deoxycorticosterone (11DB); 4 ng/mL for dihydrotestosterone (DHT), estrone (E1), estradiol (E2), estriol (E3), corticosterone (B), progesterone (P4), 17 $\alpha$-hydroxyprogesterone (17OHP4) and 17 $\alpha$-hydroxypregnenolone (17OHP5); $10 \mathrm{ng} / \mathrm{mL}$ for cortisol (F) and cortisone (E) and $40 \mathrm{ng} / \mathrm{mL}$ for dehydroepiandrosterone sulfate (DHEAS)) were compared with the results obtained after the analysis of six serum samples fortified with all the steroids considered in this work at the concentration level reported below. Results are presented in terms of percent values: a negative result indicates ion suppression while e positive result indicates ion enhancement.

\section{Carry over}

Carry over is defining as the appearance of an analyte in a sample from a preceding sample and was evaluated by the analysis of a blank sample and a mobile phase sample after the injection of the highest concentration level sample of the calibration curve, in three different analytical sessions.

\section{Stability}

Stability is defined as measure of the intactness of an analyte, described as lack of degradation in a given matrix under specific storage conditions. We evaluated the autosampler stability of the serum samples left in the autosampler of the instrument, set at $10^{\circ} \mathrm{C}$, for $24 \mathrm{~h}, 48 \mathrm{~h}$ and $72 \mathrm{~h}$.

\section{Proof of concept}

To verify the detection capability of the developed and validated method, we analyzed serum samples collected from five males (39.8 \pm 11.3$)$ and five female volunteers (43.8 \pm 12.8$)$ and compared our results with the already published reference concentration ranges (Fanelli, 2011; Eisenhofer, 2017; Schiffer, 2019) for each steroidal marker considered in the present work. 
medRxiv preprint doi: https://doi.org/10.1101/2021.04.12.21255305; this version posted April 19, 2021. The copyright holder for this preprint (which was not certified by peer review) is the author/funder, who has granted medRxiv a license to display the preprint in perpetuity.

All rights reserved. No reuse allowed without permission.

\section{Results and discussion}

\section{Method development and optimization}

\section{LC-MS/MS method development and optimization}

To evaluate ionization source and multiple reaction monitoring (MRM) transitions, the three most intense fragments of each compound (Table 1) were selected after the analysis of pure methanolic standard solutions at concentration of $10 \mu \mathrm{g} / \mathrm{mL}$ both in positive and in negative ionization mode. To improve the MRM conditions, the effects of gas temperature, collision energies, fragmentor energies, drying gas flow, sheat gas flow and sheat gas temperature were also investigated. The optimal conditions are as follow: gas temperature $200^{\circ} \mathrm{C}$, capillary voltage $3000 \mathrm{~V}$, noozle voltage $1500 \mathrm{~V}$, drying gas flow $14 \mathrm{~L} / \mathrm{min}$, sheat gas flow $11 \mathrm{~L} / \mathrm{min}$, nebulizer gas 20 psi and sheat gas temperature of $250^{\circ} \mathrm{C}$.

Different chromatographic columns were tested to study the effects of the stationary phase on the peak shapes and separation efficiency, but the best results were obtained using a $50 \mathrm{~mm}$ C18 column characterized by an internal diameter of $2,1 \mathrm{~mm}$ and a particle size of $1,8 \mu \mathrm{m}$. The use of this column provided a good separation selectivity also for isomeric compounds with the same precursor ion and similar product ions (i. e. corticosterone (B), 21-deoxycortisol (21DF) and 11-deoxycortisol (S)). Chromatographic separation of the endogenous steroids was then optimized by evaluating the use of several mobile phases (water, water with $0.1 \%$ of formic acid, water with $\mathrm{NH}_{4} \mathrm{~F} 0,2$ or $0,5 \mathrm{mM}$, acetonitrile and methanol, methanol with formic acid and methanol with $\mathrm{NH}_{4} \mathrm{~F} 0,2$ or $0,5 \mathrm{mM}$ ). The best separation was achieved using water with $\mathrm{NH}_{4} \mathrm{~F}$ 0,2 $\mathrm{mM}$ as solvent $\mathrm{A}$ and methanol with $\mathrm{NH}_{4} \mathrm{~F}$ 0,2 $\mathrm{mM}$ as solvent $\mathrm{B}$ for a total chromatographic run of 16 minutes. Mobile phases solvent composition plays a significant role in offering high chromatographic selectivity. For this, to increase the detection of compounds characterized by a negative ionization mode, we decided to use the $\mathrm{NH}_{4} \mathrm{~F}$ in both aqueous and organic mobile phase (Guo 2008; Fiers, 2012).

\section{Sample pre-treatment optimization}

During method development and optimization, various sample pre-treatment strategies, such as protein precipitation, liquid-liquid extraction and solid-phase extraction, were considered. All the strategies are characterized by advantages and limitations. Protein precipitation with acetonitrile and formic acid (1\%) can be high-throughput but less efficient in removing phospholipids which are responsible of the matrix effect analyzing endogenous steroids is serum even if it is a crucial step during the LC-MS/MS analysis of steroid esters in blood matrices (de la Torre, 2020). Solid-phase 
medRxiv preprint doi: https://doi.org/10.1101/2021.04.12.21255305; this version posted April 19, 2021. The copyright holder for this preprint (which was not certified by peer review) is the author/funder, who has granted medRxiv a license to display the preprint in perpetuity.

All rights reserved. No reuse allowed without permission.

extraction can eliminate interfering compounds from serum but requires long extraction times and could be cost-prohibitive in a high-throughput setting. Based on the above, for developing a costeffective and high-throughput sample pre-treatment procedure characterized by repeatability and highest extraction recovery, liquid-liquid extraction was selected for the identification and quantification of the steroids included in the presented method.

Different initial volume of sample (150, 250, $500 \mu \mathrm{L})$, different extraction solvents (toluene, ethyl acetate and tert-buthylmethyl ether (TBME)) added in different volume $(0.5,1,1.5,2 \mathrm{~mL})$ and different carbonate/bicarbonate buffer solution's volume (150, 200, 250 and $500 \mu \mathrm{L})$ were tested. The method was finally validated using $250 \mu \mathrm{L}$ of human serum, $150 \mu \mathrm{L}$ of carbonate/bicarbonate buffer solution and $1.5 \mathrm{~mL}$ of TBME, with the latter that is the extraction solvent that provides the highest recovery.

\section{Method validation}

The presented method was fully quantitative validated according to the U. S. Food and Drug Administration guidelines (Bioanalytical Method Validation. Guidance for Industry, 2018) in terms of selectivity/specificity, sensitivity, linearity, extraction recovery, accuracy, intra- and inter-assay precision, matrix effect, carry over and stability.

\section{Selectivity and specificity}

To assess the selectivity and the specificity of the presented analytical method six blank samples, six zero calibrator samples and six samples at $\pm 20 \%$ of LLOQ were analyzed in the same analytical session. As we can see in Figure 2 in correspondence of the retention time of all analytes, there are no peaks in the blank samples and this means that the developed method is free of interferences. Due to the endogenous origin of the analytes included in the presented method, selectivity and specificity were determined in surrogated matrices. Despite this, the ratio between quantifier ion transition and qualifier ion transitions were constantly monitored in all real samples analyzed with the presented method and compared to the calibration samples of the same batch and to the methanolic standard solutions analyzed in each session. Interference was assumed in the case of a difference greater than $30 \%$ between quantifier/qualifier ion transitions of the real sample and calibration sample.

\section{Sensitivity and lower limits of quantification (LLOQs)}

As reported in Table 2, the LLOQs are in the range of $10-400 \mathrm{pg} / \mathrm{mL}$ depending on the analyte. As requested by the FDA rules, in correspondence of each LLOQ value, the accuracy of the measurement, obtained after the analysis of at least six replicates, is in the range of $80-120 \%$ with a 
medRxiv preprint doi: https://doi.org/10.1101/2021.04.12.21255305; this version posted April 19, 2021. The copyright holder for this preprint (which was not certified by peer review) is the author/funder, who has granted medRxiv a license to display the preprint in perpetuity.

All rights reserved. No reuse allowed without permission.

$\mathrm{CV}<20 \%$ (Table 3). Each signal is also characterized by a five-fold response with the respect to the zero-calibrator, that is a blank sample fortified with the internal standard mixture.

The LLOQ values (Figure 3) are in accordance with the concentration reference ranges reported in the literature (Fanelli, 2011; Eisenhofer, 2017; Schiffer, 2019) and could be useful in the case of the analysis of serum samples collected by individual affected by metabolic disorders characterized by the reduction of concentration of endogenous steroids (i. e. hypogonadism for testosterone and other androgens or congenital adrenal hyperplasia (CAH) for cortisol and other glucocorticoids).

Furthermore, the sensitivity of the developed method, is compared to previously published assay using a higher amount of matrix $(900 \mu \mathrm{L})$ (Fanelli, 2011) or a smaller amount of matrix $(200 \mu \mathrm{L})$ (Peitzsch, 2015; Eisenhofer, 2017). For example, the amount on column of the steroid having the lowest LLOQ is 6 pg (Fanelli, 2015) or 0,7 pg (Peitzsch, 2015; Eisenhofer, 2017), while is 0,25 pg in the present work. This aspect underlines the good sensitivity levels obtained during the validation of the presented method.

\section{Linearity/calibration curves}

Due to the endogenous nature of the compounds included in the presented method, linearity experiments were assessed in surrogate matrix. To investigate the linearity, a seven points calibration's curve was established for each steroid (10 pg/mL - $10 \mathrm{ng} / \mathrm{mL}$ for androstenedione (A4), testosterone (T), 11-deoxycortisol (S), 21-deoxycortisol (21DF), 11-deoxycorticosterone (11DB); in the range $40 \mathrm{pg} / \mathrm{mL}$ - $40 \mathrm{ng} / \mathrm{mL}$ for dihydrotestosterone (DHT), estrone (E1), estradiol (E2), estriol (E3), corticosterone (B), progesterone (P4), 17 $\alpha$-hydroxyprogesterone (17OHP4) and 17 $\alpha$ hydroxypregnenolone (17OHP5); in the range $100 \mathrm{pg} / \mathrm{mL}-100 \mathrm{ng} / \mathrm{mL}$ for cortisol (F) and cortisone (E) and in the range $400 \mathrm{pg} / \mathrm{mL}$ - $1000 \mathrm{ng} / \mathrm{mL}$ for dehydroepiandrosterone sulfate (DHEA-S)) taking into account the reference concentration ranges described in the literature (Fanelli, 2011; Eisenhofer, 2017; Schiffer, 2019). In the concentration ranges here investigated all curves resulted linear with a coefficient of determination $\left(\mathrm{R}^{2}\right)$ higher than 0,99 . Furthermore, the lack-of-fit test was done for each steroid considered in the method. For each compound, the $\mathrm{F}$ calc value was minor than $\mathrm{F}$ tab value, confirming the linearity of the method.

\section{Extraction recovery}

Extraction recoveries, calculated at three different concentration levels (40 pg/ml, $1 \mathrm{ng} / \mathrm{ml}$ and 10 $\mathrm{ng} / \mathrm{mL}$ for androstenedione (A4), testosterone (T), 11-deoxycortisol (S), 21-deoxycortisol (21DF), 11-deoxycorticosterone (11DB); $100 \mathrm{pg} / \mathrm{mL}, 4 \mathrm{ng} / \mathrm{mL}$ and $40 \mathrm{ng} / \mathrm{mL}$ for dihydrotestosterone (DHT), estrone (E1), estradiol (E2), estriol (E3), corticosterone (B), progesterone (P4), 17 $\alpha$ - 
medRxiv preprint doi: https://doi.org/10.1101/2021.04.12.21255305; this version posted April 19, 2021. The copyright holder for this preprint (which was not certified by peer review) is the author/funder, who has granted medRxiv a license to display the preprint in perpetuity.

All rights reserved. No reuse allowed without permission.

hydroxyprogesterone (17OHP4) and 17 $\alpha$-hydroxypregnenolone (17OHP5); $400 \mathrm{pg} / \mathrm{mL}, 10 \mathrm{ng} / \mathrm{mL}$ and $100 \mathrm{ng} / \mathrm{mL}$ for cortisol (F) and cortisone (E); $1 \mathrm{ng} / \mathrm{mL}, 40 \mathrm{ng} / \mathrm{mL}$ and $1000 \mathrm{ng} / \mathrm{mL}$ for dehydroepiandrosterone sulfate (DHEA-S) for each steroid, were between 65 and 88 \% (Table 2) and then considered satisfactory for the application of the developed and validated method. The recovery was assessed as the mean ( $\mathrm{n}=$ six replicates for each condition considered) and standard deviation of the ratio of the peaks area before and after the extraction.

\section{Accuracy and precision}

To evaluate both accuracy and precision of the developed method in-house quality control samples (IQCs, $\mathrm{n}=$ six for each condition) at four different concentration levels - LLOQ, low, medium and high - (10 pg/mL, $40 \mathrm{pg} / \mathrm{ml}, 1 \mathrm{ng} / \mathrm{ml}$ and $10 \mathrm{ng} / \mathrm{mL}$ for androstenedione (A4), testosterone (T), 11deoxycortisol (S), 21-deoxycortisol (21DF), 11-deoxycorticosterone (11DB); 40 pg/mL, 100 pg/mL, $4 \mathrm{ng} / \mathrm{mL}$ and $40 \mathrm{ng} / \mathrm{mL}$ for dihydrotestosterone (DHT), estrone (E1), estradiol (E2), estriol (E3), corticosterone (B), progesterone (P4), 17 $\alpha$-hydroxyprogesterone (17OHP4) and 17 $\alpha$ hydroxypregnenolone (17OHP5); 100 pg/mL, 400 pg/mL, 10 ng/mL and 100 ng/mL for cortisol (F) and cortisone (E); $400 \mathrm{pg} / \mathrm{mL}, 1 \mathrm{ng} / \mathrm{mL}, 40 \mathrm{ng} / \mathrm{mL}$ and $1000 \mathrm{ng} / \mathrm{mL}$ for dehydroepiandrosterone sulfate (DHEA-S) were analyzed in three different days. The results are in accordance with the FDA criteria, underlined the applicability of the LC-MS/MS method here presented. As summarized in Table 3 the accuracy values between 85 and $115 \%$ (80-120 \% for the LLOQ level) with the respect to the nominal value and precision, measured as the coefficient of variation (CV) of the measurement, is not higher than $15 \%$ (20 \% for LLOQ level).

\section{Matrix effect}

Matrix effect was estimated after the analysis of a set of water samples fortified with all the steroids considered in the method at a single concentration level $(1 \mathrm{ng} / \mathrm{mL}$ for androstenedione (A4), testosterone (T), 11-deoxycortisol (S), 21-deoxycortisol (21DF), 11-deoxycorticosterone (11DB); 4 ng/mL for dihydrotestosterone (DHT), estrone (E1), estradiol (E2), estriol (E3), corticosterone (B), progesterone (P4), 17 $\alpha$-hydroxyprogesterone (17OHP4) and 17 $\alpha$-hydroxypregnenolone (17OHP5); $10 \mathrm{ng} / \mathrm{mL}$ for cortisol (F) and cortisone (E) and $40 \mathrm{ng} / \mathrm{mL}$ for dehydroepiandrosterone sulfate (DHEAS) and the analysis of a set of serum samples fortified at the same concentration. The concentration level selected is the mean point of the calibration curves analyzed in the present study. The results (Table 2) are expressed as ion enhancement (positive results) or ion suppression (negative results). The values of the matrix effect are lower than $15 \%$ for all the compounds included in the method and are adequate for the analysis of endogenous steroids in serum samples for clinical applications. These 
medRxiv preprint doi: https://doi.org/10.1101/2021.04.12.21255305; this version posted April 19, 2021. The copyright holder for this preprint (which was not certified by peer review) is the author/funder, who has granted medRxiv a license to display the preprint in perpetuity.

All rights reserved. No reuse allowed without permission.

results also indicate that the optimized and selected sample pre-treatment and the use of isotopiclabelled internal do not affect the quantification of the investigated serum steroids.

\section{Carry over}

The evaluation of carry over was based on the analysis of a blank serum sample and of a mobile phase sample after the analysis of the highest concentration level sample of the calibration curve in three different analytical session. No steroids were detected both in the blank sample and in the mobile phase sample underlined the absence of carry over.

\section{Stability}

To describe the stability of our matrices, the re-analysis of a set of serum sample was performed after 24, 48 and $72 \mathrm{~h}$ from their pre-treatment. The samples were left in the instrument autosampler set at $10^{\circ} \mathrm{C}$. The peak are ratios of each compound considered in the method were stable and reproducible and no loss of signal was registered. These results indicate that the analysis of each extract, over a reasonable period, is possible.

\section{Proof-of concept}

Once developed and validated, the LC-MS/MS analytical method was applied to the analysis of five serum samples collected by five different male volunteers (age: $39.8 \pm 11.3$ ) and five serum samples collected by five different female healthy subjects (age: $43.8 \pm 12.8$ ). The obtained results (Table 4) are in accordance with the previously published reference ranges (Fanelli, 2011; Eisenhofer, 2017; Schiffer, 2019), demonstration the applicability of the developed procedure for the identification and quantification of serum steroids both in male and in female individuals.

\section{Conclusions}

Here we presented the development, validation and application of an ultrasensitive liquid chromatography - tandem mass spectrometry (LC-MS/MS) method for the simultaneous analysis of sixteen endogenous steroids in human serum. The method is specific for all compounds considered and linear in the range of concentrations investigated, that are characteristic for each analyte according to their reference population ranges. The lower limits of quantification (LLOQs) and the values of intra-day and inter-day precision and accuracy are in accordance to the FDA guidelines and no matrix effect neither carry over were observed. Finally, the presented method was applied for the 
medRxiv preprint doi: https://doi.org/10.1101/2021.04.12.21255305; this version posted April 19, 2021. The copyright holder for this preprint (which was not certified by peer review) is the author/funder, who has granted medRxiv a license to display the preprint in perpetuity.

All rights reserved. No reuse allowed without permission.

analysis of serum samples collected from healthy males and females to test its application in the analysis of real samples. Based on these results, the presented method could be applied for the analysis of hormonal profile of humans subjects in whom adrenal, gonadal or combined disorders are suspected.. 
medRxiv preprint doi: https://doi.org/10.1101/2021.04.12.21255305; this version posted April 19, 2021. The copyright holder for this preprint (which was not certified by peer review) is the author/funder, who has granted medRxiv a license to display the preprint in perpetuity.

All rights reserved. No reuse allowed without permission.

Tables

Table 1: Selected $\mathrm{m} / \mathrm{z}$ transitions for the target analytes and deuterated internal standards (ISTDs) included in the developed and validated LC-MS/MS method.

\begin{tabular}{|c|c|c|c|c|c|c|}
\hline Analyte & RT (min) & $\begin{array}{c}\text { Molecular } \\
\text { weight (uma) }\end{array}$ & $\begin{array}{c}\text { Precursor ion } \\
(\mathbf{m} / \mathbf{z})\end{array}$ & $\begin{array}{c}\text { Product ions } \\
(\mathbf{m} / \mathbf{z})\end{array}$ & $\begin{array}{c}\text { Collision energy } \\
(\mathrm{eV})\end{array}$ & Polarity \\
\hline \multicolumn{7}{|c|}{ Target analytes } \\
\hline E3 & 3,4 & 288,4 & 287 & $171 ; 145$ & $40 ; 44$ & - \\
\hline $\mathrm{E}$ & 4,1 & 360,4 & 361 & 163; 91 & $24 ; 64$ & + \\
\hline F & 4,5 & 362,4 & 363 & $241 ; 121$ & $40 ; 32$ & + \\
\hline DHEA-S & 4,7 & 368,5 & 367 & $97 ; 80$ & $40 ; 40$ & - \\
\hline $21 \mathrm{DF}$ & 5,3 & 346,5 & 347 & $311 ; 105$ & $20 ; 60$ & + \\
\hline B & 5,4 & 346,5 & 347 & $121 ; 329$ & $40 ; 20$ & + \\
\hline $\mathrm{S}$ & 5,6 & 346,5 & 347 & 109; 97 & $40 ; 40$ & + \\
\hline A4 & 6,1 & 286,4 & 287 & $109 ; 97$ & $32 ; 24$ & + \\
\hline E2 & 6,4 & 272,4 & 271 & $183 ; 145$ & $52 ; 48$ & - \\
\hline E1 & 6,5 & 270,4 & 269 & $145 ; 253$ & $40 ; 40$ & - \\
\hline 11DB & 6,8 & 330,5 & 331 & 109; 97 & $28 ; 40$ & + \\
\hline $\mathrm{T}$ & 6,9 & 288,2 & 289 & $171 ; 109$ & $40 ; 32$ & + \\
\hline 17OHP4 & 7,4 & 330,5 & 331 & 109; 91 & $28 ; 40$ & + \\
\hline 17OHP5 & 7,5 & 330,5 & 331 & $185 ; 227$ & $40 ; 28$ & - \\
\hline DHT & 8,3 & 290,2 & 291 & $255 ; 77$ & $40 ; 40$ & + \\
\hline $\mathrm{P} 4$ & 9,3 & 314,5 & 315 & 109; 97 & $40 ; 20$ & + \\
\hline \multicolumn{7}{|c|}{ ISTDs } \\
\hline E-d8 & 4,0 & 368,4 & 369 & $168 ; 124$ & $28 ; 36$ & + \\
\hline F-d4 & 4,3 & 366,4 & 367 & $121 ; 97$ & $28 ; 32$ & + \\
\hline DHEA-S-d5 & 4,4 & 373,2 & 372 & $98 ; 80$ & $54 ; 60$ & - \\
\hline $21 \mathrm{DF}-d 8$ & 5,0 & 354,5 & 355 & $319 ; 46$ & $16 ; 72$ & + \\
\hline B- $d 8$ & 5,2 & 354,5 & 355 & $125 ; 337$ & $24 ; 26$ & + \\
\hline S-d7 & 5,5 & 353,5 & 354 & $113 ; 100$ & $32 ; 40$ & + \\
\hline E2-d2 & 6,3 & 274,2 & 273 & $184 ; 147$ & $44 ; 44$ & - \\
\hline 11DB-d7 & 6,6 & 337,4 & 338 & $113 ; 100$ & $24 ; 26$ & + \\
\hline $\mathrm{T}-\mathrm{d} 3$ & 6,8 & 291,2 & 292 & 109; 97 & $44 ; 30$ & + \\
\hline 17OHP4-d8 & 7,3 & 338,5 & 339 & $113 ; 100$ & $32 ; 36$ & + \\
\hline 17OHP5-d3 & 7,4 & 333,4 & 332 & $287 ; 109$ & $20 ; 28$ & - \\
\hline P4-d7 & 9,3 & 321,5 & 322 & $113 ; 100$ & $36 ; 24$ & + \\
\hline
\end{tabular}


medRxiv preprint doi: https://doi.org/10.1101/2021.04.12.21255305; this version posted April 19, 2021. The copyright holder for this preprint (which was not certified by peer review) is the author/funder, who has granted medRxiv a license to display the preprint in perpetuity.

All rights reserved. No reuse allowed without permission.

Table 2: Lower limits of quantification (LLOQs), linearity, recovery and matrix effect for all the steroids considered in the present analytical method. The recovery concentration levels are: $40 \mathrm{pg} / \mathrm{ml}$, $1 \mathrm{ng} / \mathrm{ml}$ and $10 \mathrm{ng} / \mathrm{mL}$ for androstenedione (A4), testosterone (T), 11-deoxycortisol (S), 21deoxycortisol (21DF), 11-deoxycorticosterone (11DB); $100 \mathrm{pg} / \mathrm{mL}, 4 \mathrm{ng} / \mathrm{mL}$ and $40 \mathrm{ng} / \mathrm{mL}$ for dihydrotestosterone (DHT), estrone (E1), estradiol (E2), estriol (E3), corticosterone (B), progesterone (P4), 17 $\alpha$-hydroxyprogesterone (17OHP4) and 17 $\alpha$-hydroxypregnenolone (17OHP5); 400 pg/mL, 10 $\mathrm{ng} / \mathrm{mL}$ and $100 \mathrm{ng} / \mathrm{mL}$ for cortisol (F) and cortisone (E); $1 \mathrm{ng} / \mathrm{mL}, 40 \mathrm{ng} / \mathrm{mL}$ and $1000 \mathrm{ng} / \mathrm{mL}$ for dehydroepiandrosterone sulfate (DHEA-S).

\begin{tabular}{|c|c|c|c|c|c|c|c|}
\hline \multirow{2}{*}{ Analyte } & \multirow{2}{*}{$\begin{array}{c}\text { LLOQ } \\
(\mathrm{pg} / \mathrm{mL})\end{array}$} & \multicolumn{2}{|c|}{ Linearity } & \multicolumn{3}{|c|}{$\begin{array}{l}\text { Recovery \% } \\
(\text { mean } \pm \text { sd) }\end{array}$} & \multirow{2}{*}{ Matrix effect } \\
\hline & & $\begin{array}{c}\text { Range } \\
\text { (pg/mL) }\end{array}$ & $\mathbf{R}^{2}$ & $\begin{array}{c}\text { Low range } \\
\text { (pg/mL) }\end{array}$ & $\begin{array}{c}\text { Medium range } \\
(\mathrm{pg} / \mathrm{mL})\end{array}$ & $\begin{array}{c}\text { High range } \\
(\mathrm{pg} / \mathrm{mL})\end{array}$ & \\
\hline \multicolumn{8}{|c|}{ Androgens } \\
\hline $\mathrm{T}$ & 10 & $10-10000$ & 0,9998 & $84 \pm 5,2$ & $82 \pm 6,3$ & $88 \pm 4,8$ & - 7,2\% \\
\hline DHT & 40 & $40-40000$ & 0,9997 & $76 \pm 7,7$ & $78 \pm 4,3$ & $81 \pm 5,6$ & $-5,3 \%$ \\
\hline A4 & 10 & $10-10000$ & 0,9994 & $73 \pm 2,8$ & $75 \pm 4,4$ & $79 \pm 6,3$ & $-11,8 \%$ \\
\hline DHEA-S & 400 & $400-1000000$ & 0,9967 & $65 \pm 4,8$ & $68 \pm 6,3$ & $70 \pm 3,5$ & $+14,5 \%$ \\
\hline \multicolumn{8}{|c|}{ Estrogens } \\
\hline E1 & 40 & $40-40000$ & 0,9997 & $70 \pm 7,2$ & $69 \pm 4,7$ & $73 \pm 5,5$ & $-13,2 \%$ \\
\hline E2 & 40 & $40-40000$ & 0,9994 & $74 \pm 2,4$ & $77 \pm 4,9$ & $75 \pm 3,4$ & $-9,8 \%$ \\
\hline E3 & 40 & $40-40000$ & 0,9998 & $73 \pm 5,3$ & $75 \pm 7,6$ & $79 \pm 2,8$ & - $14,8 \%$ \\
\hline \multicolumn{8}{|c|}{ Glucocorticoids } \\
\hline $\mathrm{F}$ & 100 & $100-100000$ & 0,9997 & $72 \pm 4,7$ & $75 \pm 6,3$ & $78 \pm 5,2$ & $+12,4 \%$ \\
\hline $\mathrm{E}$ & 100 & $10-100000$ & 0,9997 & $71 \pm 3,1$ & $72 \pm 6,0$ & $75 \pm 4,8$ & $+7,3 \%$ \\
\hline B & 40 & $40-40000$ & 0,9995 & $72 \pm 4,7$ & $73 \pm 6,4$ & $79 \pm 5,0$ & $-8,1 \%$ \\
\hline S & 10 & $10-10000$ & 0,9960 & $73 \pm 4,3$ & $72 \pm 6,0$ & $73 \pm 4,9$ & $+13,3 \%$ \\
\hline $21 \mathrm{DF}$ & 10 & $10-10000$ & 0,9990 & $75 \pm 3,9$ & $79 \pm 5,7$ & $76 \pm 4,4$ & $+11,7 \%$ \\
\hline $11 \mathrm{DB}$ & 10 & $10-10000$ & 0,9991 & $70 \pm 3,3$ & $72 \pm 5,6$ & $73 \pm 4,9$ & $+10,3 \%$ \\
\hline \multicolumn{8}{|c|}{ Progestagens } \\
\hline $\mathrm{P} 4$ & 40 & $40-40000$ & 0,9991 & $78 \pm 3,9$ & $82 \pm 6,3$ & $85 \pm 3,5$ & $-5,3 \%$ \\
\hline 17OHP4 & 40 & $40-40000$ & 0,9990 & $76 \pm 3,4$ & $78 \pm 4,9$ & $75 \pm 7,5$ & $-9,6 \%$ \\
\hline 17OHP5 & 40 & $40-4000$ & 0,9989 & $76 \pm 4,8$ & $75 \pm 7,5$ & $76 \pm 4,0$ & $-13,7 \%$ \\
\hline
\end{tabular}


medRxiv preprint doi: https://doi.org/10.1101/2021.04.12.21255305; this version posted April 19, 2021. The copyright holder for this preprint (which was not certified by peer review) is the author/funder, who has granted medRxiv a license to display the preprint in perpetuity.

All rights reserved. No reuse allowed without permission.

Table 3: Intra- day and inter-day accuracy and precision values for all the steroid considered in the method. The values refer to four different concentration levels (LLOQ, low level, medium level and high level) characteristic of each compound.

\begin{tabular}{|c|c|c|c|}
\hline Analyte & Conc. & Intra-day $(n=6) \%$ & Inter-day $(n=18) \%$ \\
\hline \multicolumn{4}{|c|}{ Androgens } \\
\hline \multirow{4}{*}{$\mathrm{T}$} & LLOQ: $10 \mathrm{pg} / \mathrm{mL}$ & $85 \pm 2,1$ & $82 \pm 3,6$ \\
\hline & Low level: 40 pg/mL & $91 \pm 4,6$ & $90 \pm 5,7$ \\
\hline & Medium level: 1 ng/mL & $96 \pm 5,9$ & $93 \pm 7,1$ \\
\hline & High level: 10 ng/mL & $93 \pm 4,5$ & $92 \pm 8,4$ \\
\hline \multirow{4}{*}{ DHT } & LLOQ: 40 pg/mL & $82 \pm 0,7$ & $83 \pm 0,9$ \\
\hline & Low level: 100 pg/mL & $97 \pm 10,6$ & $95 \pm 8,3$ \\
\hline & Medium level: 4 ng/mL & $104 \pm 9,5$ & $99 \pm 5,8$ \\
\hline & High level: 40 ng/mL & $100 \pm 0,7$ & $98 \pm 4,7$ \\
\hline \multirow{4}{*}{ A4 } & LLOQ: $10 \mathrm{pg} / \mathrm{mL}$ & $89 \pm 3,6$ & $114 \pm 6,3$ \\
\hline & Low level: 40 pg/mL & $94 \pm 4,7$ & $106 \pm 3,7$ \\
\hline & Medium level: 1 ng/mL & $102 \pm 8,5$ & $97 \pm 4,6$ \\
\hline & High level: 10 ng/mL & $89 \pm 1,5$ & $87 \pm 3,4$ \\
\hline \multirow{4}{*}{ DHEA-S } & LLOQ: 400 pg/mL & $85 \pm 3,5$ & $82 \pm 2,1$ \\
\hline & Low level: 1 ng/mL & $91 \pm 5,7$ & $89 \pm 3,6$ \\
\hline & Medium level: 40 ng/mL & $98 \pm 2,6$ & $97 \pm 7,2$ \\
\hline & High level: 1000 ng/mL & $98 \pm 14,3$ & $96 \pm 7,5$ \\
\hline \multicolumn{4}{|c|}{ Estrogens } \\
\hline \multirow{4}{*}{ E1 } & LLOQ: 40 pg/mL & $94 \pm 11,2$ & $92 \pm 8,7$ \\
\hline & Low level: 100 pg/mL & $104 \pm 11,2$ & $98 \pm 8,7$ \\
\hline & Medium level: 4 ng/mL & $107 \pm 7,9$ & $102 \pm 10,6$ \\
\hline & High level: 40 ng/mL & $89 \pm 1,2$ & $87 \pm 2,3$ \\
\hline \multirow{4}{*}{ E2 } & LLOQ: 40 pg/mL & $99 \pm 9,1$ & $95 \pm 6,4$ \\
\hline & Low level: 100 pg/mL & $102 \pm 5,1$ & $98 \pm 3,7$ \\
\hline & Medium level: 4 ng/mL & $95 \pm 3,6$ & $93 \pm 9,2$ \\
\hline & High level: 40 ng/mL & $97 \pm 2,9$ & $93 \pm 5,1$ \\
\hline \multirow{4}{*}{ E3 } & LLOQ: 40 pg/mL & $85 \pm 0,1$ & $83 \pm 1,5$ \\
\hline & Low level: 100 pg/mL & $109 \pm 7,6$ & $105 \pm 4,7$ \\
\hline & Medium level: 4 ng/mL & $97 \pm 6,4$ & $92 \pm 8,5$ \\
\hline & High level: $40 \mathrm{ng} / \mathrm{mL}$ & $96 \pm 0,5$ & $94 \pm 3,8$ \\
\hline
\end{tabular}


medRxiv preprint doi: https://doi.org/10.1101/2021.04.12.21255305; this version posted April 19, 2021. The copyright holder for this preprint (which was not certified by peer review) is the author/funder, who has granted medRxiv a license to display the preprint in perpetuity.

All rights reserved. No reuse allowed without permission.

\begin{tabular}{|c|c|c|c|}
\hline Analyte & Conc. & Intra-day $(n=6)$ & Inter-day $(n=18)$ \\
\hline \multicolumn{4}{|c|}{ Glucocorticoids } \\
\hline \multirow{4}{*}{$\mathrm{F}$} & LLOQ: 100 pg/mL & $103 \pm 1,8$ & $99 \pm 5,7$ \\
\hline & Low level: 400 pg/mL & $98 \pm 5,7$ & $93 \pm 8,6$ \\
\hline & Medium level: 10 ng/mL & $101 \pm 9,5$ & $96 \pm 7,2$ \\
\hline & High level: 100 ng/mL & $95 \pm 1,7$ & $92 \pm 5,8$ \\
\hline \multirow{4}{*}{ E } & LLOQ: 100 pg/mL & $83 \pm 0,5$ & $82 \pm 0,7$ \\
\hline & Low level: 400 pg/mL & $92 \pm 1,3$ & $90 \pm 3,6$ \\
\hline & Medium level: 10 ng/mL & $98 \pm 5,7$ & $96 \pm 2,1$ \\
\hline & High level: 100 ng/mL & $99 \pm 0,5$ & $97 \pm 4,6$ \\
\hline \multirow{4}{*}{ B } & LLOQ: 40 pg/mL & $112 \pm 3,4$ & $107 \pm 5,6$ \\
\hline & Low level: 100 pg/mL & $102 \pm 12,6$ & $100 \pm 7,8$ \\
\hline & Medium level: 4 ng/mL & $98 \pm 4,7$ & $96 \pm 7,3$ \\
\hline & High level: 40 ng/mL & $104 \pm 12,5$ & $101 \pm 3,7$ \\
\hline \multirow{4}{*}{ S } & LLOQ: 10 pg/mL & $82 \pm 0,3$ & $81 \pm 0,5$ \\
\hline & Low level: 40 pg/mL & $99 \pm 5,3$ & $96 \pm 1,7$ \\
\hline & Medium level: 1 ng/mL & $102 \pm 7,4$ & $98 \pm 8,3$ \\
\hline & High level: 10 ng/mL & $100 \pm 5,3$ & $96 \pm 4,6$ \\
\hline \multirow{4}{*}{$21 \mathrm{DF}$} & LLOQ: 10 pg/mL & $96 \pm 5,1$ & $93 \pm 7,8$ \\
\hline & Low level: 40 pg/mL & $95 \pm 3,7$ & $92 \pm 4,6$ \\
\hline & Medium level: 1 ng/mL & $98 \pm 6,2$ & $100 \pm 10,8$ \\
\hline & High level: 10 ng/mL & $98 \pm 3,7$ & $94 \pm 5,3$ \\
\hline \multirow{4}{*}{$11 \mathrm{DB}$} & LLOQ: $10 \mathrm{pg} / \mathrm{mL}$ & $83 \pm 1,5$ & $84 \pm 0,7$ \\
\hline & Low level: 40 pg/mL & $104 \pm 7,4$ & $101 \pm 8,5$ \\
\hline & Medium level: 1 ng/mL & $96 \pm 6,8$ & $93 \pm 4,7$ \\
\hline & High level: 10 ng/mL & $99 \pm 1,7$ & $95 \pm 5,4$ \\
\hline \multicolumn{4}{|c|}{ Progestagens } \\
\hline \multirow{4}{*}{ P4 } & LLOQ: 40 pg/mL & $83 \pm 1,7$ & $81 \pm 0,8$ \\
\hline & Low level: 100 pg/mL & $98 \pm 5,1$ & $95 \pm 4,2$ \\
\hline & Medium level: 4 ng/mL & $101 \pm 4,5$ & $99 \pm 4,6$ \\
\hline & High level: 40 ng/mL & $94 \pm 7,1$ & $92 \pm 8,4$ \\
\hline \multirow{4}{*}{ 17OHP4 } & LLOQ: 40 pg/mL & $85 \pm 1,2$ & $83 \pm 0,9$ \\
\hline & Low level: 100 pg/mL & $102 \pm 9,4$ & $97 \pm 3,6$ \\
\hline & Medium level: 4 ng/mL & $104 \pm 9,3$ & $100 \pm 9,7$ \\
\hline & High level: 40 ng/mL & $100 \pm 11,3$ & $97 \pm 7,8$ \\
\hline \multirow{4}{*}{ 17OHP5 } & LLOQ: 40 pg/mL & $86 \pm 3,1$ & $84 \pm 2,9$ \\
\hline & Low level: 100 pg/mL & $96 \pm 8,2$ & $94 \pm 2,4$ \\
\hline & Medium level: 4 ng/mL & $97 \pm 3,6$ & $95 \pm 3,9$ \\
\hline & High level: 40 ng/mL & $99 \pm 2,3$ & $97 \pm 7,5$ \\
\hline
\end{tabular}


medRxiv preprint doi: https://doi.org/10.1101/2021.04.12.21255305; this version posted April 19, 2021. The copyright holder for this preprint (which was not certified by peer review) is the author/funder, who has granted medRxiv a license to display the preprint in perpetuity.

All rights reserved. No reuse allowed without permission.

Table 4: Serum steroid concentrations obtained after the analysis of five serum sample collected from healthy male volunteers and five serum samples collected from five healthy female volunteers. The results are expressed in term of average \pm standard deviation and are compared to the reference ranges described in the literature (*: Fanelli, 2011; Eisenhofer, 2017; Schiffer, 2019).

\begin{tabular}{|c|c|c|c|c|}
\hline \multirow{2}{*}{ Analyte } & \multicolumn{2}{|c|}{ Reference ranges * $(\mathrm{ng} / \mathrm{mL})$} & \multirow{2}{*}{$\begin{array}{l}\text { Conc. }(\mathrm{ng} / \mathrm{mL}) \text { in male } \\
\text { samples }(\mathrm{n}=5)\end{array}$} & \multirow{2}{*}{$\begin{array}{c}\text { Conc. }(n g / m L) \text { in } \\
\text { female samples }(n=5)\end{array}$} \\
\hline & Male & Female & & \\
\hline \multicolumn{5}{|c|}{ Androgens } \\
\hline $\mathrm{T}$ & $0,1-8$ & $0,1-3$ & $2,2 \pm 0,4$ & $0,8 \pm 0,2$ \\
\hline$\overline{\text { DHT }}$ & $0,2-3$ & $0,05-2$ & $0,42 \pm 0,1$ & $0,12 \pm 0,05$ \\
\hline A4 & $0,2-2$ & $0,1-3$ & $0,83 \pm 0,6$ & $0,98 \pm 0,3$ \\
\hline DHEA-S & $300-3000$ & $300-3000$ & $2160 \pm 4,7$ & $1548 \pm 8,9$ \\
\hline \multicolumn{5}{|c|}{ Estrogens } \\
\hline E1 & $0,02-1$ & $0,02-1$ & $0,4 \pm 0,01$ & $0,8 \pm 0,05$ \\
\hline E2 & $0,02-1$ & $0,02-1$ & $0,3 \pm 0,05$ & $0,9 \pm 0,1$ \\
\hline E3 & $0,02-1$ & $0,02-1$ & $0,1 \pm 0,04$ & $0,5 \pm 0,03$ \\
\hline \multicolumn{5}{|c|}{ Glucocorticoids } \\
\hline $\mathrm{F}$ & $45-250$ & $40-250$ & $140 \pm 12,6$ & $167 \pm 9,5$ \\
\hline $\mathrm{E}$ & $5-50$ & $5-50$ & $28 \pm 4,6$ & $32 \pm 3,3$ \\
\hline B & $0,4-12$ & $0,4-25$ & $3,12 \pm 0,8$ & $6,2 \pm 0,5$ \\
\hline$S$ & $0,04-1$ & $0,04-0,5$ & $0,30 \pm 0,02$ & $0,28 \pm 0,03$ \\
\hline 21DF & $<<0,1$ & $<0,1$ & $0,07 \pm 0,01$ & $0,09 \pm 0,01$ \\
\hline $11 \mathrm{DB}$ & $<0,15$ & $0,3-3$ & $0,09 \pm 0,02$ & $0,42 \pm 0,1$ \\
\hline \multicolumn{5}{|c|}{ Progestagens } \\
\hline P4 & $0,01-0,2$ & $0,2-30$ & $0,07 \pm 0,02$ & $2,80 \pm 0,3$ \\
\hline 17OHP4 & $0,3-3$ & $0,1-3$ & $1,3 \pm 0,2$ & $1,2 \pm 0,4$ \\
\hline 17OHP5 & $0,3-3$ & $0,3-3$ & $0,9 \pm 0,2$ & $1,2 \pm 0,3$ \\
\hline
\end{tabular}


medRxiv preprint doi: https://doi.org/10.1101/2021.04.12.21255305; this version posted April 19, 2021. The copyright holder for this preprint (which was not certified by peer review) is the author/funder, who has granted medRxiv a license to display the preprint in perpetuity.

All rights reserved. No reuse allowed without permission.

\section{Figures}

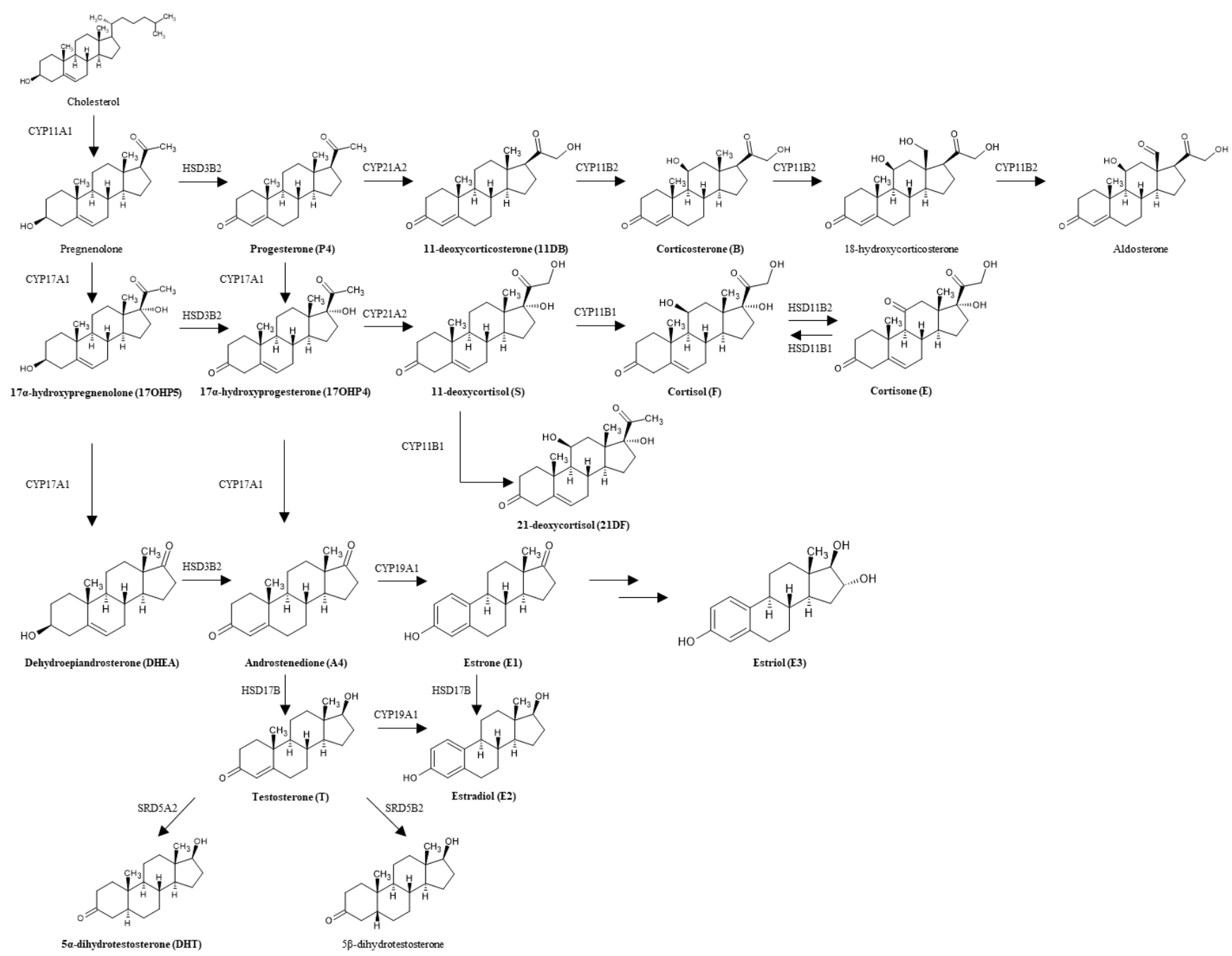

Figure 1: Biosynthetic pathway of endogenous steroid hormones. The name of the compounds considered in the proposed method are reported in bold.

CYP11A1: P450 side-chain cleavage enzyme; HSD3B2: 3 -hydroxysteroid dehydrogenase type II; CYP21A2: 21-hydroxylase; CYP11B2: aldosterone synthase; CYP17A1: 17 $\alpha$-hydrolase; CYP11B1:

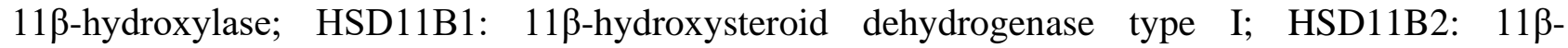
hydroxysteroid dehydrogenase type II; CYP19A1: P450 aromatase; HSD17B: 17ß-hydroxysteroid dehydrogenase; SRD5A2: $5 \alpha$-reductase type II; SRD5B2: $5 \beta$-reductase type II. 

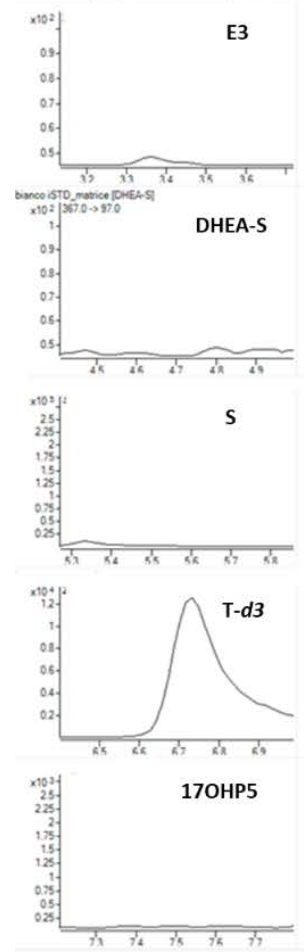
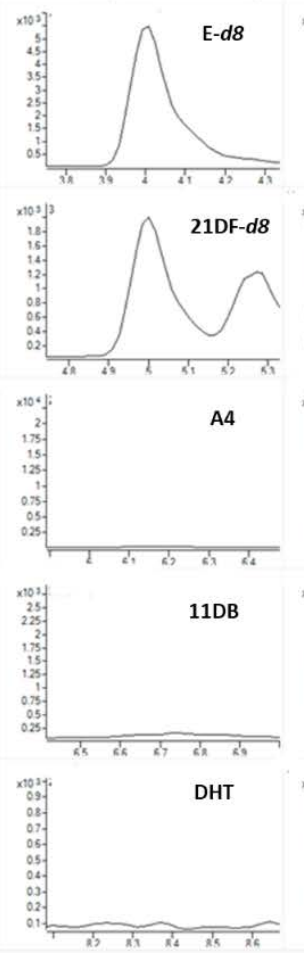

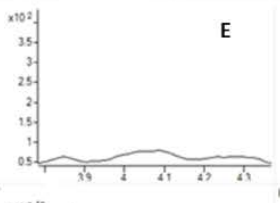

21DF

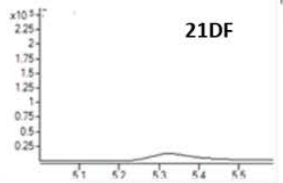

E1
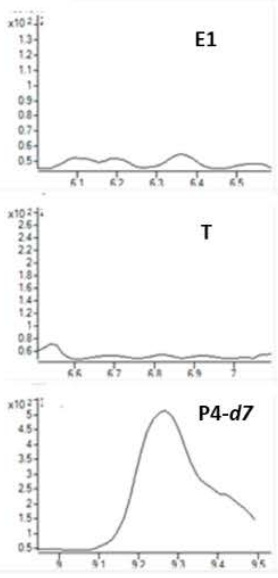
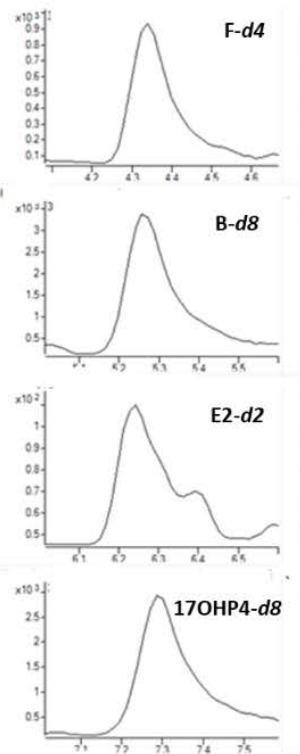

P4

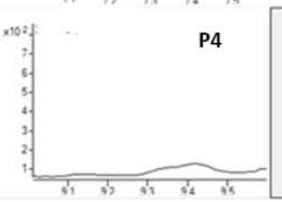

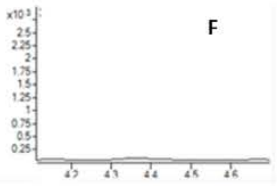

B

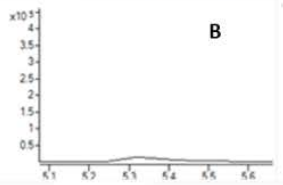

E2
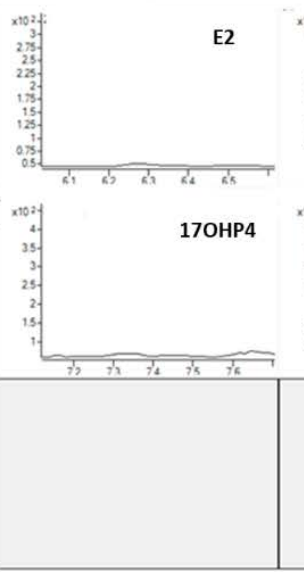
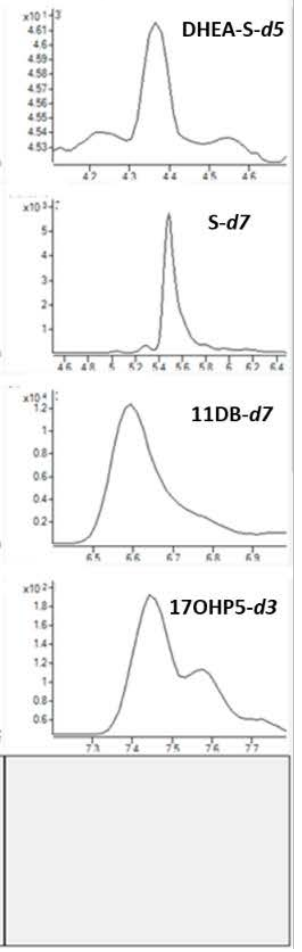

Figure 2: Extracted ion chromatogram of a blank serum samples fortified with all the deuterated internal standards considered in the presented analytical method (E-d8: 369-168, 28 eV; F-d4: 367121, 28 eV; DHEA-S-d5: 372-98, 54 eV; 21DF-d8: 355-319, 16 eV; B-d8: 355-125, 24 eV; S-d7: 354-113, 32 eV; E2-d2: 273-185, 44 eV; 11DB-d7: 338-113, 24 eV; T-d3: 292-109, 44 eV; 17OHP4d8: 339-113, 32 eV; 17OHP5-d3: 332-287, 20 eV; P4-d7: 322-113, 36 eV). 

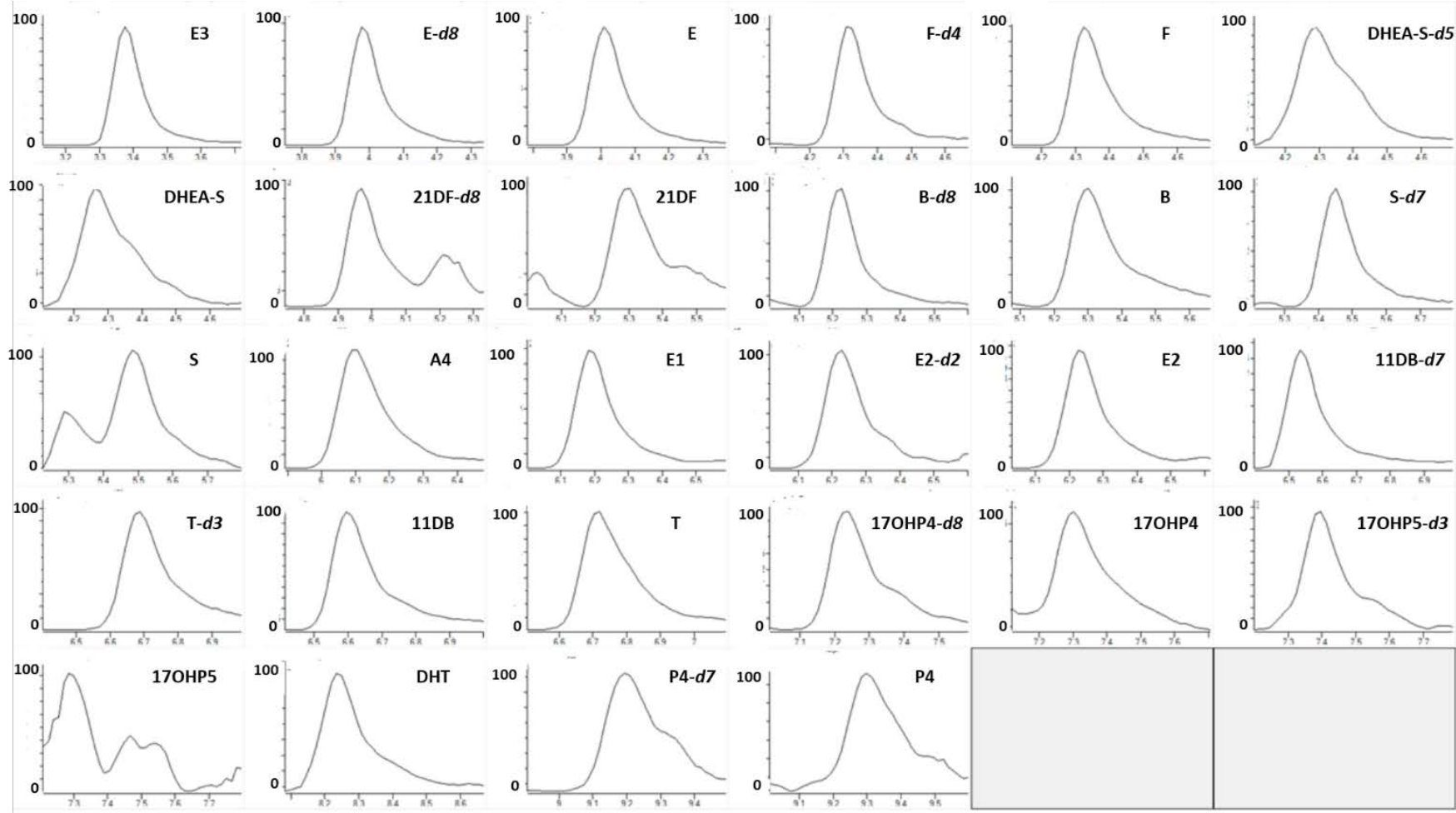

Figure 3: Extracted ion chromatogram of a LLOQ fortified serum samples (E3: 287-171, 40 eV; Ed8: 369-168, 28 eV; E: 361-163, 24 eV; F-d4: 367-121, 28 eV; F: 363-241, 40 eV; DHEA-S-d5: 37298, 54 eV; DHEA-S: 367-97, 40 eV; 21DF-d8: 355-319, 16 eV; 21DF: 347-311, 20 eV; B-d8: 355125, 24 eV; B: 347-121, 40 eV; S-d7: 354-113, 32 eV; S: 347-109, 40 eV; A4: 287-109, 32 eV; E1: 269-145, 40 eV; E2-d2: 273-185, 44 eV; E2: 271-183, 52 eV; 11DB-d7: 338-113, 24 eV; T-d3: 292109, 44 eV; 11DB: 331-109, 28 eV; T: 289-171, 40 eV; 17OHP4-d8: 339-113, 32 eV; 17OHP4: 331109, 28 eV; 17OHP5-d3: 332-287, 20 eV; 17OHP5: 331-185, 40 eV; DHT: 291-255, 40 eV; P4-d7: 322-113, 36 eV; P4: 315-109, 40 eV). 
medRxiv preprint doi: https://doi.org/10.1101/2021.04.12.21255305; this version posted April 19, 2021. The copyright holder for this preprint (which was not certified by peer review) is the author/funder, who has granted medRxiv a license to display the preprint in perpetuity.

\section{References}

Auchus, R. J. (2014). Steroid assays and endocrinology: best practices for basic scientists. Endocrinology, 155, 2049-2051.

Aversa, A., Isidori, A. M., Greco, E. A., Giannetta, E., Gianfrilli, D., Spera, E., Fabbri, A. (2004). Hormonal supplementation and erectile dysfunction. European Urology, 45, 535-538.

Buiarelli, F., Cartoni, G. P., Amendola, A., Botrè, F. (2001) Screening and confirmation analysis of anabolic agents in human urine by gas chromatography-hybrid mass spectrometry (high resolution-time of flight) Analytica Chimica Acta, 447, 75-88.

Carvalho, V. M. (2012). The coming of age of liquid chromatography coupled to tandem mass spectrometry in the endocrinology laboratory. Journal of Chromatography B, 883-884, 50-58.

Caulfield, M. P., Lynn, T., Gottschalk, M. E., Jones, K. L., Taylor, N. F., Malunowicz, E. M., Shackleton, C. H., Reitz, R. E. and Fisher, D. A. (2002). The diagnosis of congenital adrenal hyperplasia in the newborn by gas chromatography/mass spectrometry analysis of random urine specimens. The Journal of Clinical Endocrinology and Metabolism, 87, 3682-3690.

de la Torre, X., Iannone, M., Botrè, F. (2021). Improving the detection of anabolic steroid esters in human serum by LC-MS. Journal of Pharmaceutical and Biomedical Analysis, 194, doi: 10.1016/j.jpba.2020.113807.

Di Luigi, L., Sgrò, P., Aversa, A., Migliaccio, S., Bianchini, S., Botrè, F., Romanelli, F., and Lenzi, A. (2012). Concerns about serum androgens monitoring during testosterone replacement treatments in hypogonadal male athletes: a pilot study. Journal of Sexual Medicine, 9, 873-886.

Di Luigi, L., Sgrò, P., Romanelli, F., Mazzarino, M., Donati, F., Braganò, M. C., Bianchini, S., Fierro, V., Casasco, M., Botrè, F. and Lenzi, A. (2009). Urinary and serum hormones profiles after testosterone enanthate administration in male hypogonadism: concerns on the detection of doping with testosterone in treated hypogonadal athletes. Journal of Endocrinological Investigation, 32, 445453.

Eisenhofer, G., Peitzsch, M., Kaden, D., Langton, K., Pamporaki, C., Masjkur, J., Tsatsaronis, G., Mangelis, A., Williams, T. A., Reincke, M., Lenders, J. W. M. and Bornstein, S. R. (2017). Reference intervals for plasma concentrations of adrenal steroids measured by LC-MS/MS: Impact of gender, age, oral contraceptives, body mass index and blood pressure status. Clinica Chimica Acta, 470, 115124.

Fanelli, F., Belluomo, I., Di Lallo, V. D., Cuomo, G., De Iasio, R., Baccini, M., Casadio, E., Casetta, B., Vicennati, V., Gambineri, A., Grossi, G., Pasquali, R. and Pagotto, U. (2011). Serum steroid 
medRxiv preprint doi: https://doi.org/10.1101/2021.04.12.21255305; this version posted April 19, 2021. The copyright holder for this preprint (which was not certified by peer review) is the author/funder, who has granted medRxiv a license to display the preprint in perpetuity.

All rights reserved. No reuse allowed without permission.

profiling by isotopic dilution-liquid chromatography-mass spectrometry: Comparison with current immunoassays and reference intervals in healthy adults. Steroids, 76, 244-253.

Fiers, T., Casetta, B., Bernaert, B., Vandersypt, E., Debock, M., Kaufman, J. M. (2012). Development of a highly sensitive method for the quantification of estrone and estradiol in human serum by liquid chromatography tandem mass spectrometry without derivatization. Journal of Chromatography B, 893-4, 57-62.

Frati, P., Busardò, P. F., Cipolloni, L., De Dominicis, E., and Fineschi, V. (2015). Anabolic androgenic steroid (AAS) related deaths: autoptic, histopathological and toxicological findings. Current Neuropharmacology, 13, 146-159.

Giannetta, E., Gianfrilli, D., Barbagallo, F., Isidori, A. M., Lenzi, A. (2012). Subclinical male hypogonadism. Best Practice \& Research Clinical Endocrinology \& Metabolism, 26, 539-550.

Grebe, S. K. and Singh, R. J. (2011). LC-MS/MS in the clinical laboratory - where to from here? Clinical Biochemist Reviews, 32, 5-31.

Guo, T., Gu, J., Soldin, O. P., Singh, R. J., Soldin, S. J. (2008). Rapid measurement of estrogens and their metabolites in human serum by liquid chromatography-tandem mass spectrometry without derivatization. Clinical Biochemistry, 41, 736-741.

Handelsman, D. J. (2017). Mass spectrometry, immunoassay and valid steroid measurements in reproductive medicine and science. Human reproduction, 32, 1147-1150.

Handelsman, D. J., Teede, H. J., Desai, R., Norman, R. J. And Moran L. J. (2017). Performance of mass spectrometry steroid profiling for diagnosis of polycystic ovary syndrome. Human Reproduction, 32, 418-422.

Iannone, M., Palermo, A., de la Torre, X., Mazzarino, M., Molaioni, F., Botrè, F. Influence of Saw palmetto and Pygeum africana extracts on the urinary concentrations of endogenous anabolic steroids: Relevance to doping analysis. Phytomedicine Plus, doi: 10.1016/j.phyplu.2020.100005.

Iannone, M., Palermo, A., de la Torre, X., Romanelli, F., Sansone, A., Sansone, M., Lenzi, A. and Botrè, F. (2019). Effects of transdermal administration of testosterone gel on the urinary steroid profile in hypogonadal men: implications in antidoping analysis. Steroids, 152, 108491.

Isidori, A. M., Kaltsas, G. A., Perry, L., Burrin, J. M., Besser, G. M., Monson, J. P. (2003). The effect of growth hormone replacement therapy on adrenal androgen secretion in adult onset hypopituitarism. Clinical Endocrinology, 58, 601-611.

Isidori, A. M., Pozza, C., Gianfrilli, D., Isidori, A. (2006). Medical treatment to improve sperm quality. Reproductive BioMedicine Online, 12, 704-714. 
medRxiv preprint doi: https://doi.org/10.1101/2021.04.12.21255305; this version posted April 19, 2021. The copyright holder for this preprint (which was not certified by peer review) is the author/funder, who has granted medRxiv a license to display the preprint in perpetuity.

Isidori, A. M., Balercia, G., Calogero, A. E., Corona, G., Ferlin, A., Francavilla, S., Santi, D., Maggi, M. (2015). Outcomes of androgen replacement therapy in adult male hypogonadism: recommendations from the Italian society of endocrinology, 38, 103-112.

Isidori, A. M., Arnaldi, G., Boscaro, M., Falorni, A., Giordano, C., Pivonello, R., Pozza, C., Sbardella, E., Simeoli, C., Scaroni, C., Lenzi, A. (2020). Towards the tailoring of glucocorticoid replacement in adrenal insufficiency: the Italian Society of Endocrinology Expert Opinion. Journal of Endocrinological Investigation, 43, 683-696.

Ismail, A. A., Walker, P. L., Cawood, M. L. and Barth J. H. (2002). Interference in immunoassay is an underestimated problem. Annals of Clinical Biochemistry, 39, 366-373.

Keevil, B. G. (2016). LC-MS/MS analysis of steroids in the clinical laboratory. Clinical Biochemistry, 49, 989-997.

Koal, T., Schmiederer, D., Pham-Tuan, H., Rohring, C. and Rauh M. (2012). Standardized LCMS/MS based steroid hormone-profile analysis. Journal of Steroid Biochemistry and Molecular Biology, 129, 129-138.

Krone, N., Hughes, B. A., Lavery, G. G., Stewart, P. M., Arlt, W., and Shackleton, C. H. (2010). Gas chromatography/mass spectrometry (GC/MS) remains a pre-eminent discovery tool in clinical steroid investigation even in the era of fast liquid chromatography tandem mass spectrometry (LC/MS/MS). Journal of Steroid Biochemistry and Molecular Biology, 121, 496-504.

Kushnir, M. M., Rockwood, A. L., Roberts, W. L., Yue, B., Bergquist, J., and Meikle, A. W. (2011). Liquid chromatography tandem mass spectrometry for analysis of steroids in clinical laboratories. Clinical Biochemistry, 44, 77-88.

Minnetti, M., Hasenmajer, V., Pofi, R., Vanneri, M. A., Alexandraki, K. I., Isidori, A. M. (2020). Fixing the broken clock in adrenal disorders: focus on glucocorticoids and chronotherapy. Journal of Endocrinology, 246, R13-R31.

Minutti, C. Z., Lacey, J. M., Magera, M. J., Hahn, S. H., Mc Cann, M., Schulze, A., Cheillan, D., Dorche, C., Chace, D. H., Lymp, J. F., Zimmerman, D., Rinaldo, P., \& Matern, D. (2004). Steroid profiling by tandem mass spectrometry improves the positive predictive value of newborn screening for congenital adrenal hyperplasia. The Journal of Clinical Endocrinology and Metabolism, 89, 36873693.

Narducci, W. A., Wagner, J., C., Hendrickson, T. P. and Jeffrey, T. P. (1990). Anabolic steroids - a review of the clinical toxicology and diagnostic screening. Clinical Toxicology, 28, 287-310.

Othonos, N., Marjot, T., Woods, C., Hazlehurst, J. M., Nikolaou, M., Pofi, R., White, S., Bonaventura, I., Webster, C., Duffy, J., Cornfield, T., Moolla, M., Isidori, A. M., Hodson, L., Tomlinson, J. W. (2020). Co-administration of $5 \alpha$-reductase inhibitors worsens the adverse metabolic 
medRxiv preprint doi: https://doi.org/10.1101/2021.04.12.21255305; this version posted April 19, 2021. The copyright holder for this preprint (which was not certified by peer review) is the author/funder, who has granted medRxiv a license to display the preprint in perpetuity.

All rights reserved. No reuse allowed without permission.

effects of prescribed glucocorticoids. The Journal of Clinical Endocrinology and Metabolism, 105, e3316-e3328.

Palermo, A., Botrè. F., de la Torre, X., Fiacco, I., Iannone, M. and Mazzarino, M. (2016). Drug-drug interactions and masking effects in sport doping: influence of miconazole administration on the urinary concentrations of endogenous anabolic steroids. Forensic Toxicology, 34, 386-397.

Peitzsch, M., Dekkers, T., Haase, M., Sweep, F. C. G. J., Quack, I., Antoch, G., Siegert, G., Lenders, J. W. M., Deinum, J., Willenberg, H. S., Eisenhofer, G. (2015). An LC-MS/MS method for steroid profiling during adrenal venous sampling for investigation of primary aldosteronism. Journal of Steroid Biochemistry and Molecular Biology, 145, 75-84.

Peitzsch, M., Dekkers, T., Haase, M., Sweep, F. C., Quack, I., Antoch, G., Siegert, G., Lenders, J. W., Deinum, J., Willenberg, H. R. and Eisenhofer, G. (2015). An LC-MS/MS method for steroid profiling during adrenal venous sampling for investigation of primary aldosteronism. Journal of Steroid Biochemistry and Molecular Biology, 145, 75-84.

Peng, S-H., Segura, J., Farrè, M., Gonzalez, J. C. and de la Torre, X. (2002). Plasma and urinary markers of oral testosterone undecanoate misuse. Steroids, 67, 39-50.

Pofi, R., Feliciano, C., Sbardella, E., Argese, N., Woods, C. P., Grossman, A. B., Jafar-Mohammadi, B., Gleeson, H., Lenzi, A., Isidori, A. M., Tomlinson, J. W. (2018). The short synacthen (Corticotropin) test can be used to predict recovery of hypothalamo-pituitary-adrenal axis function. The Journal of Clinical Endocrinology and Metabolism, 103, 3050-3059.

Ponzetto, F., Boccard, J., Baume, N., Kuuranne, T., Rudaz, S., Saugy, M. and Nicoli, R. (2017). Highresolution mass spectrometry as an alternative detection method to tandem mass spectrometry for the analysis of endogenous steroids in serum. Journal of Chromatography B, 1052, 34-42.

Ponzetto, F., Mehl, F., Boccard, J., Baume, N., Rudaz, S., Saugy, M. and Nicoli, R. (2016). Longitudinal monitoring of endogenous steroids in human serum by UHPLC-MS/MS as a tool to detect testosterone abuse in sports. Analytical and Bioanalytical Chemistry, 408, 705-719.

Rosner, W., Auchus, R. J., Azziz, R., Sluss, P. M. and Raff, H. (2007). Utility, limitation and pitfalls in measuring testosterone: an Endocrine Society position statement. The Journal of Clinical Endocrinology and Metabolism, 92, 405-413.

Schiffer, L., Barnard, L., Baranowski, E. S., Gilligan, L. C., Taylor, A. E., Arlt, W., Shackleton, C. H. L. and Storbeck, K-H. (2019). Human steroid biosynthesis, metabolism and excretion are differentially reflected by serum and urine steroid metabolomes: A comprehensive review. Journal of Steroid Biochemistry and Molecular Biology, 194, doi: 10.1016/j.jsbmb.2019.105439. 
medRxiv preprint doi: https://doi.org/10.1101/2021.04.12.21255305; this version posted April 19, 2021. The copyright holder for this preprint (which was not certified by peer review) is the author/funder, who has granted medRxiv a license to display the preprint in perpetuity.

All rights reserved. No reuse allowed without permission.

Shackleton, C. H. (2010). Clinical steroid mass spectrometry: a 45-year history culminating in HPLCMS/MS becoming an essential tool for patient diagnosis. Journal of Steroid Biochemistry and Molecular Biology, 121, 481-490.

Shackleton, C. H., Kletke, C., Wudy, S. and Pratt, J. H. (1990). Dehydroepiandrosterone sulfate quantification in serum using high-performance liquid chromatography/mass spectrometry and a deuterated internal standard: a technique suitable for routine use or as a reference method. Steroids, 55, 472-478.

Shackleton, C. H., Pozo, O. J., Marcos, J. (2018). GC/MS in recent years has defined the normal and clinically disordered steroidome: will it soon be surpassed by LC/tandem MS in this role? Journal of the Endocrine Society, 2, 974-996.

Soldin, S. J. and Soldin, O. P. (2009). Steroid hormone analysis by tandem mass spectrometry. Clinical Chemistry, 55, 1061-1066.

Stanczyk, F. Z., Cho, M. M., Endres, D. B., Morrison J. L., Patel, S. and Paulson R. J. (2003). Limitations of direct estradiol and testosterone immunoassy kits. Steroids, 68, 1173-1178.

Stoll, A., Iannone M., De Gregorio, G., de la Torre, X., Molaioni, F., Botrè, F., Parr, M. K. Influence of pain killers on the urinary anabolic steroid profile. Journal of Analytical Toxicology, 44, 871-879. Stoll, A., Iannone M., De Gregorio, G., de la Torre, X., Molaioni, F., Botrè, F., Parr, M. K. Influence of Indomethacin on Steroid Metabolism: Endocrine Disruption and Confounding Effects in Urinary Steroid Profiling of Anti-Doping Analyses. Metabolites, 10, 463-482.

Storbeck, K-H., Schiffer, L., Baranowski, E. S., Chortis, V., Prete, A., Barnard, L., Gilligan, L. C., Taylor, A. E., Idkowiak, J., Arlt, W. and Shackleton, C. H. (2019). Steroid metabolome analysis in disorders of adrenal steroid biosynthesis and metabolism. Endocrine Reviews, 40, 1605-1625.

Taylor, D. R., Ghataore, L., Couchman, L., Vincent, R. P., Whitelaw, B., Lewis, D., Diaz-Cano, S., Galata, G., Schulte, K. M., Aylwin, S. and Taylor, N. F. (2017). A 13-steroid serum panel based on LC-MS/MS: use in detection of adrenocortical carcinoma. Clinical Chemistry, 63, 1836-1846.

U. S. Department of Health and Human Services, Food and Drug Administration. Bioanalytical Method Validation. Guidance for Industry (2018).

Vogeser, M. and Parhofer, K. G. (2007). Liquid chromatography-tandem mass spectrometry (LCMS/MS) technique and application in endocrinology. Experimental and Clinical Endocrinology and Diabetes, 115, 559-570.

Wolthers, B. G. and Kraan, G. P. (1990). Clinical applications of gas chromatography and gas chromatography-mass spectrometry of steroids. Journal of Chromatography A, 843, 247-274. 